\title{
Fiscal Stabilizations: When Do They Work and Why
}

\section{Citation}

Ardagna, Silvia. 2004. Fiscal stabilizations: when do they work and why. European Economic Review 48(5): 1047-1074.

\section{Published Version}

http://dx.doi.org/10.1016/j.euroecorev.2003.09.010

\section{Permanent link}

http://nrs.harvard.edu/urn-3:HUL.InstRepos:2580047

\section{Terms of Use}

This article was downloaded from Harvard University's DASH repository, and is made available under the terms and conditions applicable to Other Posted Material, as set forth at http:// nrs.harvard.edu/urn-3:HUL.InstRepos:dash.current.terms-of-use\#LAA

\section{Share Your Story}

The Harvard community has made this article openly available.

Please share how this access benefits you. Submit a story.

\section{Accessibility}




\title{
Fiscal Stabilizations: When Do They Work and Why
}

\author{
Silvia Ardagna* \\ Wellesley College
}

July 2002

Revised July 2003

European Economic Review - Forthcoming

\begin{abstract}
This paper studies the determinants and channels through which fiscal contractions influence the dynamics of the debt-to-GDP ratio and GDP growth. Using data from a panel of OECD countries, the paper shows that the success of fiscal adjustments in decreasing the debt-to-GDP ratio depends on the size of the fiscal contraction and less on its composition. The rate of growth of output matters too, but higher GDP growth does not drive the success of a fiscal stabilization. In contrast, whether a fiscal adjustment is expansionary depends largely on the composition of the fiscal manoeuvre. In particular, stabilizations implemented by cutting public spending lead to higher GDP growth rates. The effects of the composition on growth work mostly through the labor market rather than through agents' expectations of future fiscal policy. Finally, the evidence suggests that successful and expansionary fiscal contractions are not the result of accompanying expansionary monetary policy or exchange rate devaluations.
\end{abstract}

\footnotetext{
${ }^{*}$ I am very grateful to Alberto Alesina and Fabio Schiantarelli for their suggestions and comments and for their encouragement. I also thank seminar participants at Bocconi University, Boston College, Boston College-Boston University macro-seminar, University of California Santa Cruz, University of Rome La Sapienza, University of Tilburg, University of Warwick, The World Bank, Wellesley College, Richard Arnott, Francesco Caselli, Giancarlo Corsetti, Alejandro Cunat, Mariassunta Giannetti, Francesco Giavazzi, Peter Gottschalk, Claudio Gnessutta, Peter Ireland, Marco Lippi, Tommaso Monacelli, Gerard Pfann, Roberto Perotti, James Poterba, Marco Zenezin, and two anonymous referees for very useful suggestions.

Silvia Ardagna, Department of Economics, Wellesley College, Wellesley, MA 02481, sardagna@wellesley.edu.
} 


\section{Introduction}

After years of loose fiscal policy in the seventies and early eighties, many OECD countries had to return to fiscal discipline. Consequently, starting from the mid-eighties, several governments undertook austere fiscal programs. As many recent papers have highlighted, the response of the economy to these fiscal adjustments has varied substantially: in some cases (but not in all) the fiscal tightening led to a reduction of the debt-to-GDP ratio; in several episodes (but not in all) private consumption, private investment, and GDP growth rates increased during the consolidation and in its immediate aftermath, contrary to the predictions of a standard Keynesian model. ${ }^{1}$

This paper studies empirically the determinants of the different outcomes that characterize fiscal adjustment programs in the OECD countries. The paper focuses on the medium-term response of the debt-to-GDP ratio and on GDP growth, and tests the importance of the alternative channels through which tight fiscal policies lead to the stabilization of the debt-to-GDP ratio and to a boom in the economy.

Two non-mutually exclusive explanations have been proposed for successful (i.e. leading to a reduction of the debt-to-GDP ratio) and expansionary (i.e. leading to a boom in the economy) fiscal stabilizations. One view is related to the impact that current fiscal policy has on the economy through its influence on agents' expectations about the stance of the future fiscal policy (the expectation view). This literature predicts that a fiscal contraction can be expansionary if agents perceive that the adjustment signals a change in regime that will lead to the stabilization of the debt-to-GDP ratio and solve the country's fiscal imbalance. For example, the fiscal contraction generates a positive wealth effect and aggregate demand can increase if, in response to an increase in current taxation, agents expect that fiscal policy in the future need not be tighter, or even anticipate a reduction in the tax burden. The other view stresses the effect of the composition of current fiscal policy (whether the deficit reduction is achieved through tax increases or through spending cuts) on the economy through the labor market and the cost side of the firms (the labor market view). This view suggests that stabilizations that result from cutting public spending, especially transfers and government wage bills, rather than increasing taxes are more likely to be successful and expansionary. They induce a moderation in the wage claims by unions, stimulating employment, capital accumulation, and growth. ${ }^{2}$

There is evidence of both channels in the literature, but there has been no attempt to provide an overall

\footnotetext{
${ }^{1}$ See, for example, Alesina and Ardagna (1998), Alesina and Perotti (1995), Alesina, Perotti and Tavares (1998), Giavazzi and Pagano (1990) and (1996), and McDermot and Wescott (1996).

${ }^{2}$ See Blanchard (1990), Bertola and Drazen (1993), Miller et al. (1990), and Sutherland (1997) for models that explain expansionary fiscal contractions through the expectation channel, and Alesina et al. (2002), Alesina and Perotti (1997), and Daveri and Tabellini (2000) for contributions that explain expansionary fiscal contractions through the labor market channel.
} 
empirical assessment of their relative importance. One of the goals of this paper is to bridge this gap. The evidence presented here shows that the composition of fiscal policy is a crucial element for growth and that the labor market is an important channel for the transmission of fiscal policy shocks. In fact, controlling for the impact that fiscal policy has on GDP growth through its effect on expectations, the economy booms when government spending and, especially, governments' wage bills are cut, and it slows down when taxes increase. Also, as the labor market view suggests, there is no evidence that the effect of changes to public spending and taxation on growth is different in periods of large fiscal stabilizations than in other times and that large fiscal contractions per se increase economic activity. Instead, the occurrence of a large fiscal contraction has a positive effect on growth through its effect on agents' expectations about future fiscal policy; however, the variable measuring agents' expectations is statistically significant only in some specifications. As far as the ability of governments to reduce the debt-to-GDP ratio, the size of the fiscal manoeuvre is a key variable. The probability that tight fiscal policies lead to a decrease in the debt-to-GDP ratio increases the larger the decrease in public spending and the increase in taxes, and it almost doubles when governments engage in large fiscal adjustments.

The paper reaches some additional interesting conclusions. First, current GDP growth does not drive the success of a stabilization. An important criticism of the empirical literature that relates the success of a fiscal manoeuvre to its size and composition is that it does not account for differences in GDP growth rates. Successful fiscal adjustments can result simply from higher GDP growth (due, for example, to other policy measures) rather than from discretionary fiscal policy choices. The evidence of this paper shows that current GDP growth matters, but that the effects of fiscal policy characteristics on the likelihood of a success do not vanish when one controls for the effect of GDP growth. Second, the paper investigates whether successful and expansionary fiscal adjustments hinge on countries' initial conditions. Obstfeld (1998), among others, argues that the macroeconomic effects of fiscal adjustments depend on initial conditions, in particular on whether or not fiscal policy is on a sustainable course. The paper shows that the initial level of the debt as a share of GDP has a positive and statistically significant effect on the probability of a success, but the estimated coefficient of the initial level of the deficit-to-GDP ratio is negative. However, results do not change if one includes in the sample only country-years with high initial levels of public debt, government deficit and primary spending. Finally, the evidence shows that episodes of successful and expansionary fiscal contractions are not simply due to expansionary monetary policy and exchange rate devaluations implemented to offset the fiscal contraction, as some previous research has suggested. In fact, controlling for the stance of monetary policy does not alter the conclusions on the determinants and the channels through which fiscal policy influences the economy. 
This paper is related to Alesina and Ardagna (1998), Alesina and Perotti (1995), Alesina, Perotti, and Tavares (1998), and McDermott and Wescott (1996). However, it differs from these papers along several dimensions. First, it employs a different methodology: the previous papers draw their conclusions on the basis of descriptive statistics on the characteristics of different fiscal adjustments and on their macroeconomic outcomes. In contrast, this paper relies on an econometric analysis to reach the results described above. Second, this paper is the first to try to assess econometrically the importance of the channels through which fiscal policy induces a reduction in the debt-to-GDP ratio and an expansion in output. Third, it improves upon Alesina and Ardagna (1998) and on McDermott and Wescott (1996) by addressing the joint endogeneity of the likelihood that governments implement successful fiscal contractions and of GDP growth, and by controlling for the stance of monetary and exchange rate policies around the time of the adjustment. Finally, the paper explicitly accounts for the fact that what matters for economic activity is not only the current discretionary reduction in the deficit, but also the resulting expectations about the stance of future fiscal policy. Previous research on the expectation view does not estimate agents' expectations that the adjustment will lead to a sustainable level of the debt-to-GDP ratio in the future; instead, it proxies the effect that current fiscal policy has on agents' expectations about the stance of future fiscal policy with a dummy variable measuring the size of the improvement in the budget.

The paper is organized as follows. Section 2 summarizes the theories that explain the expansionary fiscal contractions. Section 3 describes the econometric and data issues and illustrates the specification for the benchmark model. Section 4 discusses the results, and section 5 checks their robustness. The last section concludes.

\section{A review of the literature}

The so-called "expectation view" and the "labor market view" suggest two channels of transmission of fiscal policy shocks that help explaining why in some cases, but not in all, fiscal adjustments led to a reduction of the debt-to-GDP ratio and to higher GDP growth rates. These two views are not mutually exclusive nor exhaust all possible channels through which fiscal stabilizations can generate an increase in economic activity. However, they have been suggested in the literature as the most important theories to explain expansionary fiscal contractions and there is a difference in emphasis by various authors on which channel matters most. This section briefly summarizes the expectation and labor market views and, then, discusses an additional potential channel for expansionary fiscal contractions.

The expectation view focuses on the demand side and predicts that fiscal stabilizations may be expansionary 
if agents believe that the fiscal tightening generates a change in regime that "eliminates the need for larger, maybe much more disruptive adjustments in the future" (Blanchard (1990)). Consider, for example, a country that is running a deficit resulting in increasing public debt. To satisfy its intertemporal budget constraint, the government implements at some point in time a debt-stabilization program. Assume that the stabilization consists of increases in taxes and that the deadweight cost of taxation increases with the tax rate. In this scenario, the longer the government waits to stabilize (hence, the higher the tax rate required), the greater the costs and the permanent distortions of the fiscal adjustment. Hence, an increase in current taxation removes the danger of an even sharper and more costly fiscal adjustment in the future, generating a positive wealth effect. This may induce an increase in current private consumption and in aggregate demand. Similarly, a stabilization achieved by cutting public spending can be expansionary if the cut is expected to be permanent and generates a positive wealth effect that outweights the decrease in current disposable income following the fall in public spending. ${ }^{3}$ An additional channel trough which current fiscal policy can influence the economy via its effect on agents' expectations is the interest rate. If agents believe that the stabilization is credible and avoids a default on government debt, they can ask for a lower premium on government bonds. Private demand components sensitive to the real interest rate can increase if the reduction in the interest rate paid on government bonds leads to a reduction in the real interest rate charged to consumers and firms. ${ }^{4}$

Let's now turn to the labor market view, which focuses on the supply-side, and let me clarify right away that expectations can play a role in models that emphasize the effect of fiscal policy through the labor market too. However, as discussed below, in these models, the occurrence of expansionary fiscal contractions does not depend on whether or not agents perceive that the fiscal stabilization generates a change in regime that solves the country's fiscal imbalance. It depends, instead, on the composition of fiscal policy shocks through their effects on labor costs of private sector firms. Traditionally, the supply-side effects of fiscal policy have been studied in

\footnotetext{
${ }^{3}$ Note that if taxes were lump-sum, and there were no distortions in the economy that prevent infinitely lived agents from smoothing their consumption optimally over time, Ricardian equivalence would hold. Also, if agents have a finite life and are not altruistic, or if they are liquidity constrained, a increase in current taxation (or a decrease in public spending) may also have large negative effect on private consumption, reducing agents' disposable income. Current private consumption booms only if the positive wealth effect from the increase in taxation (or from the decrease in public spending) is large enough to outweigh the negative one on current disposable income. See Blanchard (1990), Bertola and Drazen (1993), Miller et al. (1990), Perotti (1999), and Sutherland (1997).

${ }^{4}$ The decrease in interest rate can also lead to the appreciation of stocks and bonds, increasing agents' financial wealth, and triggering a consumption/investment boom. Moreover, if agents believe that the stabilization eliminates the danger of a default crisis and have quite a substantial share of their wealth in government bonds, they can be willing to consume and invest more, because the adjustment removes the uncertainty about the "availability" of this part of their wealth.
} 
the context of a standard neoclassical model with perfectly competitive labor markets (see, for instance, Baxter and King (1993), Ludvigson (1996), and Olivei (1999)). Recently, the literature has shifted the focus to models with imperfect and unionized labor markets that reflect in a more realistic way the labor markets' nature of most OECD countries and deliver predictions more consistent with the empirical evidence from episodes of fiscal stabilizations. Assume an economy with a unionized labor market as, for example, the one in Ardagna (2002) or Maffezzoli (2001). Consider first a fiscal stabilization implemented by an increase in income taxes or in social security contributions paid by the workers. For a given pre-tax real wage, these policy shocks lower workers' after-tax real wage and induce unions to ask for an increase in the pre-tax real wage. The equilibrium wage rate increases leading to a reduction of the equilibrium level of employment and of the shadow value of capital, with negative effects on capital accumulation and on growth. Consider, now, a fiscal stabilization that relies on cuts to public spending. A decrease in government employment, in government wages, and in unemployment benefits can have positive effects on the economy because it makes the labor market less tight and weakens unions' power. In fact, a decrease in public employment increases the probability of being unemployed. Because public employment represents an alternative to private employment, lower levels of the former or of public wages also decrease the reservation utility of unions' members. Similarly, a decrease in unemployment benefits or in transfers increases the cost of being unemployed. Any decrease in these public spending items lowers pressure on the equilibrium wage with positive consequences for the economy. Note that a general equilibrium model with a perfectly competitive labor market, as the one in Finn (1998), also delivers the result that a decrease in public employment increases employment in the private sector and boosts output. Instead, in a standard neoclassical model with perfectly competitive labor markets, predictions on the effect of changes to other spending and revenue items are, in general, sensitive to the persistence of the policy change, to the financing method, and to the elasticity of the individual labor supply. ${ }^{5}$

Finally, in section 4, the paper investigates an additional channel through which a fiscal stabilization can lead to an increase in economic activity. If public investment and private investment are substitutes, a fiscal stabilization achieved by cutting public investment leads to an increase in private investment. GDP growth will increase if private investment is more productive than public investment.

\footnotetext{
${ }^{5}$ See Alesina et al. (2002) for a review of the literature that compares the effects of fiscal policy on the supply-side in models with perfect and imperfect labor markets.
} 


\section{Methodology, data, and benchmark specification}

This section describes the methodology applied for the estimation, the data, and the benchmark specification. First, the section discusses the single equation approach, which I use to estimate the ability governments have to solve fiscal imbalances. I calculate agents' expectations that the fiscal contraction will lead, within a few years, to the stabilization of the debt-to-GDP ratio. Then, I use this variable as a regressor in the GDP growth equation to provide an overall empirical assessment of the relative importance of the expectation view. The section also presents a simultaneous equations approach, which takes into account a potential problem of simultaneity between governments' ability to solve a fiscal imbalance and GDP growth. Finally, the section discusses the choice of the sample and the data.

\subsection{Single equation approach}

\subsubsection{Modelling the probability of a successful stabilizations}

The ability/propensity of a government to solve a fiscal imbalance, $s^{*}$, is a latent variable not directly observed. The paper assumes, instead, that we observe a discrete variable $s . \quad s$ indicates whether or not governments undertake discretionary cuts in the deficit-to-GDP ratio and obtain, within a few years, a reduction in the debt as a share of GDP. There are two reasons one may want to follow this approach. First, the literature on the macroeconomic effects of fiscal adjustments is not concerned with small and continuous changes in the debt as a share of GDP. Rather, it looks at the impact of large and persistent reductions in the public debt-to-GDP ratio that result from discretionary improvements in the budget. Second, as discussed in section 2, whether a fiscal adjustment has a positive effect on the economy may depend on agents' perception that the stabilization leads to a change in the fiscal regime. A small and continuous change in the debt-to-GDP ratio that does not result from any improvement in the budget can hardly be interpreted as a change in fiscal policy regime that eliminates the need for future tightening. Thus, this paper uses a limited dependent variable estimation method and estimates the following probit model for $s^{*}$ as basic specification:

$$
\begin{gathered}
s_{i t}^{*}=\vartheta_{1 i}+\gamma_{1} y_{i t-1}+a_{11} \Delta G_{i t}+a_{12} \Delta T_{i t}+a_{13} D E F_{i t-1}+a_{14} D E B_{i t-1}+ \\
+a_{15} \text { Left }_{i t}+a_{16} \text { Centre }_{i t}+a_{17} \text { Major }_{i t}+u_{1 i t} \equiv Z_{1 i t} \delta_{1}+u_{1 i t} \\
s_{i t}=\left\{\begin{array}{l}
1 \text { if } s_{i t}^{*}>0 \\
0 \text { otherwise }
\end{array}\right.
\end{gathered}
$$


and

$$
s_{i t}^{e}=E\left[s_{i t}^{*} \mid I_{t}\right]=Z_{1 i t} \delta_{1}
$$

where $i=\{1, \ldots, I\}$ indicates the countries in the sample; $t=\{1, \ldots ., T\}$ the annual observation; $y$ measures the real per capita GDP growth rate; $\Delta G$ measures the change in the cyclically adjusted primary expenditure as a share of GDP; $\triangle T$ the change in cyclically adjusted tax revenue as a share of GDP; $D E F$ and $D E B$ are the ratios of government deficit and public debt to GDP respectively; Left, and Centre are dummy variables equal to one if the government in office is left or centre oriented and zero otherwise; Major is a dummy variable equal to one if a single party has the majority in the Parliament and zero otherwise. From equation (2), we observe a successful fiscal adjustment if $s_{i t}^{*}>0$. In the basic model, a successful fiscal stabilization $\left(s_{i t}=1\right)$ is an episode in which the cyclically adjusted primary balance improves, and, two years after, the debt-to-GDP ratio is at least three percentage points lower than in the year of the fiscal tightening. ${ }^{6}$ Equation (3) describes agents' expectations about $s_{i t}^{*}$ and assumes that the variables on the right-hand side of (1) belong to agents' information set at time $t$. This assumption is not too far from reality, or, at least, is less implausible than the alternative. Politicians usually discuss and approve the budget for year $t$ during the second half of year $t-1$. Sometimes they make additional fiscal policy changes during year $t$, but they usually represent a small fraction of the budget. Moreover, fiscal policy variables have been cyclically adjusted following Blanchard (1993) to correct for the automatic changes in their values due to business cycle fluctuations and to consider only the effect of changes to fiscal policy due to discretionary policy choices. ${ }^{7}$

Based on the discussion in section 2, agents' expectations about governments' ability to solve a country's fiscal imbalance should depend both on the size of the improvement in the primary deficit and on the way in which the improvement is obtained. In fact, the larger the cut in the deficit, the more people expect that the current fiscal package can stabilize the debt-to-GDP ratio and, hence, remove the need for further fiscal tightening in the future, (see Feldstein (1982)). Moreover, agents can believe that governments that reduce spending, especially the "untouchable" items of the budget (transfers, government wages, public employment), are more serious and committed to solve the fiscal imbalance than governments that increase taxation. They are willing to undertake

\footnotetext{
${ }^{6}$ This definition uses the same threshold value for the reduction of the debt-to-GDP ratio as the one in McDermott and Wescott (1996). Section 5 shows that results are robust to alternative definitions of successful fiscal adjustments.

${ }^{7}$ The cyclical correction calculates what the fiscal policy item would have been if the unemployment rate were equal to that of the benchmark year. The discretionary change of the fiscal policy variable is the difference between the cyclically adjusted variable and the value of the variable in the previous year. See Alesina and Perotti (1995) for a detailed description of the method and for a discussion about its advantages over the methods used by the OECD and the IMF.
} 
unpopular policy measures, which, most likely, will have more permanent effects on the budget. This suggests that we should observe $a_{11}<0$ : for given changes in taxes, larger cuts in government spending increase the probability of a success implying both a tighter fiscal policy and a fiscal policy composition based on spending cuts. Instead, the sign of $a_{12}$ (the coefficient of tax variable) is in theory ambiguous. Suppose, in fact, that the change in the primary balance is the only characteristic of fiscal policy that matters for governments' ability to obtain a reduction in the debt-to GDP ratio. In this case, the higher the increase in taxation, the higher the probability that the debt-to-GDP ratio decreases. Hence, $a_{12}>0$. If, instead, the composition of the fiscal manoeuvre, but not the size, matters, then, for given changes in government spending, larger increases in taxes should have a negative effect on $s^{*}$.

To determine whether the size and/or the composition of fiscal policy affect governments' ability to solve countries' fiscal imbalances and test the relative importance of these two characteristics of fiscal stabilizations, the following restrictions on the coefficients estimated in equation (1) can be tested: (i) $H_{0}: a_{11}+a_{12}=0$; (ii) $H_{0}$ : $a_{11}-a_{12}=0$. Consider first (i). It investigates whether fiscal policy composition has no effect on $s^{*}$, and, hence, whether the change in the primary balance is the only characteristic of fiscal policy that can affect governments' ability to implement a successful fiscal contraction. Specifically, if the data reject $H_{0}$, governments' ability to solve countries fiscal imbalances will also depend on the composition of the fiscal manoeuvre. Assume, instead, that the data do not reject $H_{0}$. In this case, $a_{11}=-a_{12}$, which suggests that the only variable that matters is the change in the primary balance. Consider now (ii). If the data do not reject $H_{0}$, then $a_{11}=a_{12}$, implying that the composition of the fiscal manoeuvre is the only variable that is important. If, instead, the data reject $H_{0}$, the size of the change in the primary deficit will also affect $s^{*}$. Alternatively, one can investigate the relative importance of the size and the composition of the fiscal manoeuvre by reparametrizing equation (1) as follows:

$$
\begin{aligned}
s_{i t}^{*}= & \vartheta_{1 i}+\gamma_{1} y_{i t-1}+b_{11}\left(\Delta G_{i t}-\Delta T_{i t}\right)+b_{12}\left(\Delta G_{i t}+\Delta T_{i t}\right)+a_{13} D E F_{i t-1}+ \\
& +a_{14} D E B_{i t-1}+a_{15} \text { Left }_{i t}+a_{16} \text { Centr }_{i t}+a_{17} \text { Major }_{i t}+u_{1 i t}
\end{aligned}
$$

In equation (4) the effect of the size and that of the composition can be captured by the coefficients $b_{11}$ and $b_{12}$, where $b_{11}=\left(a_{11}-a_{12}\right) / 2, b_{12}=\left(a_{11}+a_{12}\right) / 2$, and $a_{11}, a_{12}$ are the coefficients in equation (1). A negative value of $b_{11}$ indicates that larger improvements in the primary balance increase the probability of a success; a negative $b_{12}$ is evidence of a "right" fiscal policy composition. In fact, the variable $(\Delta G+\Delta T)$ assumes negative values when both government spending and taxes are cut (the "best" fiscal policy in terms of composition as it happened in the 1987 - 1989 Irish stabilization) and positive values when both variables 
increase (the "worst" fiscal policy in terms of composition). Note, however, that in measuring the effect of the composition by estimating $b_{12}$, equation (4) restricts changes in taxes and government spending to have the same effect on $s^{*}$.

The benchmark model also controls for countries' initial conditions (the initial level of the deficit and debt to GDP ratios, and the lagged GDP growth rate), political variables describing the type and the ideology of the government in office, and country fixed effects. The statistical evidence on episodes of fiscal adjustments suggests that successful stabilizations are more likely to occur in "bad" rather than in "good" times. For example, Obstfeld (1998) argues that a deterioration of the fiscal position makes it "easier" for the government in office to undertake reforms that can lead to a successful stabilization. ${ }^{8}$ Sutherland (1997) suggests that, at higher levels of debt, fiscal adjustments are more likely to increase economic activity. This can ease the reduction of the debt-to-GDP ratio, increasing the denominator of the ratio. Political characteristics of the government in office can also play a role beyond their effect on the size and composition of fiscal policy. For example, agents might believe that left-wing governments have more chances to stabilize the debt-to-GDP ratio than right-wing ones. Because of the left's support from unions and from pensioners, they can communicate the need for the adjustment and stick to their policy in the future more easily. ${ }^{9}$ Similarly, agents might think that single-party majority governments are less likely to abandon the program in the future than are coalition or minority cabinets.

\subsubsection{GDP growth}

Equation (5) describes the real per capita GDP growth regression:

$$
\begin{array}{rlr}
y_{i t}= & \vartheta_{2 i}+\gamma_{2} s_{i t}^{e}+a_{21} \Delta G_{i t}+a_{22} \Delta T_{i t}+a_{23} D E F_{i t-1}+a_{24} D E B_{i t-1}+ \\
& +a_{25} y_{i t-1}+a_{26} y_{i t-1}^{G 7}+u_{2 i t} \equiv Z_{2 i t} \delta_{2}+u_{2 i t} \quad u_{2 i t} \sim N\left(0, \sigma_{2}^{2}\right)
\end{array}
$$

where: $s_{i t}^{e}$ is generated using equation (3) and the estimates from equation (1); $y, s^{e}, \Delta G, \Delta T, D E F$, and $D E B$ are defined as in section 3.1.1, and $y^{G 7}$ measures the weighted average (with GDP weights) real per capita

\footnotetext{
${ }^{8}$ Equation (1) already controls for the effect of the size and the composition of the fiscal package. Hence, Obstfeld's argument applies to policy measures that do not have a contemporaneous effect on the change in primary spending and government revenues. For example, the proceeds of privatizations that occurred in Italy in the 1990s did not finance the budget deficit but a special fund used to buy back government bonds and decrease the stock of public debt. To the extent that such measures are more likely to occur when countries' fiscal positions deteriorate, we can observe positive and statistically significant coefficients for the initial level of public debt and/or government deficit.

${ }^{9}$ This argument is similar to the one in Cukierman and Tommasi (1998). See also Kontopoulus and Perotti (2002) for a review of the theory and for an empirical analysis on the effects of the ideology and fragmentation of the governments on the deficit to GDP ratio and/or in its components.
} 
GDP growth rate of the G7 countries. Equation (5) is estimated by OLS. However, since it includes a generated regressor, $s_{i t}^{e}$, the conventional standard errors of the coefficients are not consistent (unless $\gamma_{2}$ is statistically insignificant). ${ }^{10}$ I correct the standard errors following Murphy and Topel (1985). The correction allows $u_{1 i t}$ and $u_{2 i t}$ to be correlated.

A positive and statistically significant coefficient of the variable measuring agents' expectations (i.e.: $\gamma_{2}$ ) shows evidence in favor of the expectation view. The more agents perceive that the government is able to solve the fiscal imbalance, the more they expect that future fiscal policy does not need to be as tight as current fiscal policy, and both private current consumption and investment can increase, leading to higher GDP growth. As for effect of changes to primary spending and government revenues on GDP growth, once we control for the expectation channel including $s^{e}$ among the regressors in (5), $\Delta G$ and $\Delta T$ can affect the macroeconomy through the other channels discussed in section 2 or through the standard Keynesian channel. Decreases in taxes have a positive effect on the economy both according to the labor market view and in a standard Keynesian model. Decreases in public spending have negative effect on growth in a Keynesian model. Instead, according to the labor market view decreases to government spending and, especially to the government wage bill and welfare payments, boost growth. Similarly, decreases in public investment can lead to higher private investment and growth if public investment is a substitute for private investment and the former is less productive than the latter. Hence, we can interpret $a_{21}<0$ as evidence in favor of the labor market view, particularly if the spending variables that change are public employment, wages of government employees and transfers. If, instead, the change in total government spending is mainly due to changes to public investment, then, a negative value of $a_{21}$ can be evidence of the crowding-in effect of private investment following the cut to government investment. Table 3 investigates the effect of changes of single spending components (government wage bill, public employment, an government investment) on GDP growth to provide more evidence on the channels through which changes to fiscal policy can influence the economy beyond the expectation channel.

Following the empirical strategy in section 3.1.1, the paper uses the estimates of the coefficients $a_{21}$ and $a_{22}$ in equation (5) to run hypothesis tests similar to (i) - (ii) above and evaluate the relative importance of the size versus the composition of the fiscal manoeuvre in explaining expansionary fiscal adjustments. The paper also reparametrizes equation (5) as:

$$
\begin{aligned}
y_{i t}= & \vartheta_{2 i}+\gamma_{2} s_{i t}^{e}+b_{21}\left(\Delta G_{i t}-\Delta T_{i t}\right)+b_{22}\left(\Delta G_{i t}+\Delta T_{i t}\right)+ \\
& +a_{23} D E F_{i t-1}+a_{24} D E B_{i t-1}+a_{25} y_{i t-1}+a_{26} y_{i t-1}^{G 7}+u_{2 i t}
\end{aligned}
$$

\footnotetext{
${ }^{10}$ See Pagan (1984) and (1986). Note, however, that the coefficients estimates are consistent.
} 
and captures the effect of the size and the composition with the coefficients $b_{21}$ and $b_{22}$, where $b_{21}=\left(a_{21}-a_{22}\right) / 2$, $b_{22}=\left(a_{21}+a_{22}\right) / 2$, and $a_{21}, a_{22}$ are the coefficients in equation (5).

\subsection{Simultaneous equations approach}

The single equation approach assumes that GDP growth influences governments' ability to solve a fiscal imbalance only with a lag. If, instead, $s^{*}$ depends also on current GDP growth, then, there is a problem of simultaneity in the procedure described in section 3.1. In fact, if $s^{*}$ and $y$ are endogenous, estimates of the effects of $s^{e}$ on GDP growth without controlling for the effect of current growth on $s^{*}$ are biased. To address this issue, I also estimate the equation describing governments' ability to solve countries fiscal imbalances and the growth equation simultaneously. The basic model is described by equations (7) and (8):

$$
\begin{aligned}
s_{i t}^{*}= & \vartheta_{1 i}+\gamma_{1} y_{i t}+a_{11} \Delta G_{i t}+a_{12} \Delta T_{i t}++a_{13} D E F_{i t-1}+a_{14} D E B_{i t-1}+ \\
& +a_{15} \text { Left }_{i t}+a_{16} \text { Centre }_{i t}+a_{17} \text { Major }_{i t}+u_{1 i t} \\
y_{i t}= & \vartheta_{2 i}+\gamma_{2} s_{i t}^{e}+a_{21} \Delta G_{i t}+a_{22} \Delta T_{i t}+a_{23} D E F_{i t-1}+a_{24} D E B_{i t-1}+ \\
& +a_{25} y_{i t-1}+a_{26} y_{i t-1}^{G 7}+u_{2 i t}
\end{aligned}
$$

where $\left[\begin{array}{ll}u_{1 i t} & u_{2 i t}\end{array}\right]^{\prime} \sim N(0, \Omega)$ and $s$ and $s^{e}$ are defined respectively by equations (2) and (3) above. ${ }^{11}$ The coefficients $\gamma_{1}$ and $\gamma_{2}$ now take into account the contemporaneous effect among $s^{*}, s^{e}$ and $y . a_{11}-a_{17}$, and $a_{21}$ - $a_{26}$ measure the impact of the exogenous variables described in section 3.1. Because $s^{*}$ is a latent variable, I estimate equations (7) and (8) applying Amemiya's (1978) generalized least square technique (AGLS). Newey (1987) shows that AGLS is asymptotically equivalent to the minimum $\chi^{2}$ estimation procedure, and that, in overidentified systems, AGLS is efficient relative to 2IV estimators. ${ }^{12}$

To estimate (7) and (8), the system needs to be identified. The identification of the system requires that at least one exogenous variable in the equation for $s^{*}$ is not included in the equation for growth and vice-versa. In the benchmark model, political variables do not enter the growth equation directly. The literature on political business cycles shows that the type and the ideology of the government in office affect fiscal policy variables.

\footnotetext{
${ }^{11}$ The specification assumes that agents know current growth when they form their expectations on governments' ability to stabilize the debt-to-GDP ratio. Alternatively, one can argue that agents do not know the contemporaneous growth rate but they use the forecast data on GDP growth. In this case, one introduces a forecast error in (8). The estimates are still consistent because the estimation method allows for cross-equations correlation between the errors in (7) and (8).

${ }^{12}$ See Appendix B of the working paper version of this paper (Wellesley College working paper 2002-08, July 2002), and Amemiya (1978), Newey (1987), and Londregan and Poole (1990) for details on the AGLS estimation procedure.
} 
Through the latter, political variables can influence the macroeconomy. Moreover, section 3.1 argues that political characteristics of the government in office can also affect agents' expectations. Because the rhs of equation (8) already includes both fiscal policy variables and the variable capturing agents' expectations, it does not seem unreasonable to assume that Left, Centre, and Major do not influence GDP growth directly. The identification of the system also assumes that the lagged real per capita GDP growth rate and the lagged real per capita GDPweighted growth rate of the G7 countries influence governments' ability to stabilize successfully only indirectly, through their effect on current GDP growth. The AGLS technique allows easily to test the overidentifying restrictions of the system and the empirical analysis will show that the model does not reject the overidentifying restrictions at conventional confidence levels.

\subsection{Sample choice and data}

What is the more appropriate sample of country-years one should consider to estimate the determinants of the different outcomes of fiscal adjustments in the OECD countries? This papers argues that the sample should include country-years in which there is a "need" for fiscal austerity. Most of the empirical literature on fiscal adjustments has, instead, considered only country-years in which there is evidence of large discretionary fiscal policy tightening. On the one hand, including in the sample also country-years in which there is no concern for the state of public finance and no need for fiscal austerity can bias the estimate of the coefficient $\gamma_{2}$ downward. In such circumstances, agents' expectations about governments' ability to solve a fiscal imbalance play no role and if we include these observations in the sample, we cannot distinguish cases in which we do not observe a successful stabilization because there is no need for it from cases in which a stabilization is needed but governments are not able to carry one out. On the contrary, information from country-years in which fiscal discipline is a problem, but governments do not undertake discretionary and substantial deficit cuts, is valuable to consumers and investors. Most likely, such inaction influences agents' expectations about the stance of future fiscal policy. Thus, one loses valuable information by including in the sample only those episodes in which there is evidence of large fiscal contractions. In the benchmark model, the sample includes 17 OECD countries (Australia, Austria, Belgium, Canada, Denmark, Finland, France, Greece, Ireland, Italy, Japan, the Netherlands, Norway, Spain, Sweden, United Kingdom, and the United States) from 1975 to 2002. ${ }^{13}$ As figure 1 shows, the average debt-to-GDP

\footnotetext{
${ }^{13}$ Two small OECD countries, Luxembourg and Iceland, are excluded, together with members of this group admitted recently. New Zealand, Portugal, and Switzerland are excluded because of data problems. Finally, Germany is not included in the sample for econometric reasons. Because the equation for governments' ability to solve countries' fiscal imbalances is estimated with a probit model, and because country fixed effects are always included among the regressors, the effects that the explanatory variables have on $s^{*}$ cannot be estimated for
} 
ratio of the OECD countries is almost constant in the sixties, decreases from 1968 to 1974, and rapidly increases afterward. Thus, it seems reasonable to assume that countries became concerned about the state of public finance after the first oil shock. Moreover, as Alesina and Ardagna (1998) show, in all the countries listed, there has been one or more episodes of fiscal consolidation after 1974, which is evidence that, at least during some years, fiscal restraint was an issue of concern. Section 5 checks that results are robust to different sets of country-years included in the sample.

Economic data are from the OECD Economic Outlook n.72, December 2002. The political data up to 1990 and for all countries except Greece and Spain are from Budge, Keman, and Woldendrop (1993). Data for Greece and Spain, and for the period 1990-2002 are from various issues of the Political Handbook of the World.

\section{Empirical results}

\subsection{Basic specifications}

Columns 1 - 4 of Table 1 show the results from the single equation approach; columns 5 - 8 present the results from the simultaneous equation approach. Let's begin by discussing the determinants of a successful fiscal stabilization, starting with column 1. First of all, both larger decreases in government spending and larger increases in taxes have a positive effect on governments' ability to implement a fiscal contraction and induce within a few years a decrease of the debt-to-GDP ratio. A one percentage point decrease in government spending as a share of GDP increases the likelihood of a success from 0.19 to 0.27 and a one percentage point increase in taxes raises the probability of a success from 0.19 to $0.30 .{ }^{14}$ These effects are statistically significant at the $5 \%$ level. Second, the success of a fiscal adjustment depends on the size of the fiscal contraction and less on its composition. In fact, the data strongly reject the null hypothesis that the composition of fiscal policy is the only characteristic of the manoeuvre that is important $\left(H_{0}: a_{11}-a_{12}=0\right)$, while they reject only at the $10 \%$ level the null hypothesis that the change of the primary balance is the only variable that counts for $s^{*}\left(H_{0}\right.$ :

countries in which $s$ does not vary over time. In Germany, the data do not show any episode of successful fiscal adjustment when the latter is defined as in section 3.1 .1 or in section 5 .

${ }^{14}$ To calculate the effect of a $1 \%$ change in a continuous variable on $s^{*}$, I consider the difference between the average probability of success using the estimated coefficients and the data in the sample and the value of this same variable calculated assuming that the continuous variable is $1 \%$ higher (or lower) than in the actual data. The effect of a change of a dummy variable from 0 to 1 is measured as the difference between the average probability calculated if the dummy variable is equal to zero and the average probability calculated if the dummy variable is equal to one. I evaluate the average probability of success using the estimated coefficients and the data in the sample. I adopt this method throughout the paper. Alternatively, I could have measured the probability evaluating it at the average value of the explanatory variables. 
$a_{11}+a_{12}=0$ ). Results for equation (4), the reparametrized version of equation (1), are in column 3 and clearly show the different roles of the size and the composition of fiscal policy. On the one hand, the coefficient of the change in the primary deficit as a share of GDP, $(\Delta G-\Delta T)$, is statistically significant at the $5 \%$ level and its magnitude implies that, ceteris paribus, a one percentage point improvement in the primary balance-to-GDP ratio increases the probability of success from 0.19 to 0.28 . On the other hand, the coefficient of the variable that measures the effect of the composition $(\Delta G+\Delta T)$ is significant only at the $10 \%$ level and the magnitude of the coefficient suggests that an increase by one percentage point in $(\Delta G+\Delta T)$ increases $s^{*}$ only by one percent, from 0.19 to 0.20 . Note that the sign of the coefficient of the composition variable is positive and, hence, opposite to the one suggested by previous literature. The statistical evidence on episodes of fiscal adjustments has highlighted that fiscal consolidations are more likely to be successful if they rely sharply on spending cuts. Results in columns 1 and 3, instead, suggest that increases in taxes have a stronger effect on $s^{*}$ than decreases in government spending. Among the other regressors, past economic growth has a positive and statistically significant impact on $s^{*}$, but its effect is small: a one percentage point increase in lagged GDP growth increases the probability that the government is able to solve a fiscal imbalance from 0.19 to 0.21 . Countries' initial fiscal conditions have, instead, an ambiguous effect. On the one hand, a higher level of the deficit-to-GDP ratio decreases governments' likelihood to stabilize public debt. On the other, a higher stock of public debt increases the chances of a success. Finally, left-wing governments are more likely to stabilize the debt than right-wing ones. There is, however, no evidence that a different type of government (majority versus coalition governments) influences agents' expectations about the dynamics of the debt-to-GDP ratio.

Columns 2 and 4 show the results for the growth equation in the single equation approach. Column 2 presents the estimates of the benchmark specification in equation (5). Larger cuts to public spending increase GDP growth and the magnitude of the coefficient is quite large. If governments reduce the share of primary spending-to-GDP by one additional percentage point, GDP growth increases by half percentage point. The effect is significant at the 5\% level. Tax reductions and agents' expectations about governments' ability to solve a fiscal imbalance, instead, do not have a statistically significant effect on GDP growth, even though the sign of both variables is consistent with the theories summarized in section 2. The tests on the coefficients of $\Delta G$ and $\Delta T$ suggest that the composition of fiscal policy is the only characteristic that matters for growth, while the change in the primary balance-to-GDP ratio has no effect. In fact, the null hypothesis $H_{0}: a_{21}-a_{22}=0$ cannot be rejected, while the null hypothesis $H_{0}: a_{21}+a_{22}=0$ is rejected by the data. Results (not shown but available upon request) of the estimation of the reparametrized model in equation (6) confirm the tests' results. Including 
the regressor that measures the effect of the change in the primary balance, $(\Delta G-\Delta T)$, and the one that captures the effect of the composition, $(\Delta G+\Delta T)$, the coefficient of the former is not statistically significant, while the one of the latter is significant at the 5\% level. Finally, note that agents' expectations about governments' ability to solve countries' fiscal imbalances do not have a statistically significant effect on GDP growth.

To further investigate the impact that fiscal policy characteristics have on GDP growth through their effects on expectations, I estimate equation (6) imposing the restriction $a_{21}-a_{22}=0$ and, hence, allowing the change in the primary balance $(\Delta G-\Delta T)$ to influence growth only through $s^{e}$, but not directly. Results are in column 4 . In this specification, the coefficient of the variable measuring agents' expectations about governments' ability to solve countries' fiscal imbalances, $s^{e}$, is positive and statistically significant, which provides some evidence in favor of the expectation view. Note also that the coefficient of the variable measuring the effect of the composition of the fiscal manoeuvre remains negative and statistically significant. Moreover, if one estimates the equations in columns 2 and 4 by instrumenting the fiscal policy variables $(\Delta G, \Delta T$, and $\Delta G+\Delta T)$ with the once lagged and twice lagged value of the changes in government spending, government revenues and of the variable measuring agents' expectations about governments' ability to solve countries' fiscal imbalances, results are virtually unchanged. Actually, the estimated coefficients of $\Delta G$ and of $\Delta G+\Delta T$ are even larger in absolute value than those in Table 1. This suggests that the negative and statistically significant effect that government spending has on GDP growth is not due to a potential endogeneity problem between $\Delta G$ and $y$ that could, for example, occurr if the cyclical adjstment method used were not perfect or if the government decided and implemented during a given year, after the approval of the budget, large additional fiscal policy measures.

Results from the simultaneous equations approach are in columns $5-8$. They are very similar to the ones obtained in the single equation approach. The effect of current real GDP growth on $s^{*}$ is larger than that of past economic growth. The probability that governments are able to solve a fiscal imbalance increases by 6 percentage points from 0.20 to 0.26 when real GDP growth is one percentage point higher. Previous studies have been criticized because they failed to take into account the feedback effects from GDP growth on the likelihood of a successful stabilization. Columns 5 and 7 show that the coefficient of current growth is significant but high economic growth does not drive the success of a consolidation. In fact, controlling for current growth, fiscal policy variables have the same effect on $s^{*}$ than in columns 1 and 3 , except for the variable measuring the effect of the composition of the fiscal manoeuvre which is now statistically significant at the $5 \%$ level. Note, also, that the $\chi^{2}$ tests of the overidentifying restrictions do not reject the estimated models at least at the $10 \%$ confidence level. 
In summary, i) the probability that tight fiscal policies lead to a decrease in the debt-to-GDP ratio depends on the size of the improvement in the primary balance and less on its composition; ii) higher GDP growth favors the success of a fiscal contraction but it is not the only important determinant of governments' ability to solve countries' fiscal imbalances; iii) controlling for the impact that fiscal policy characteristics have on GDP growth through their effects on expectations, the paper finds that GDP growth is higher the larger the decrease in public spending. There is no evidence that the change in the primary balance per se affects economic activity. Instead, the size of a fiscal contraction has a positive effect on growth through its effect on agents' expectations about future fiscal policy. In fact, in some specifications, agents' beliefs about governments' ability to solve a fiscal imbalance have a positive effect on growth.

\subsection{Non-linear effects of changes in fiscal policy}

According to the expectation view, not only the improvement in the primary balance and the way in which the improvement is obtained can have a positive effect on $s^{*}$ and $s^{e}$, but the effects of changes to fiscal policy variables can be nonlinear. For example, agents can believe that the stabilization will be successful only if the reduction in the primary deficit is substantial. To the contrary, the labor market view does not suggest that there is any difference in the reaction of the economy to small versus large fiscal adjustments or to fiscal adjustments versus fiscal expansions. In fact, both a fiscal stabilization implemented by a decrease in public spending and a fiscal expansion that relies on cuts to labor taxes can generate an increase in economic activity. To provide evidence on the relative importance of the expectation versus the labor market channel, I now investigate whether the response of $s^{*}$ and/or $y$ to fiscal policy shocks is non-linear. I begin by adding to the equations estimated in Table 1, columns $5-8$, the square of the variables $\Delta G$ and $\Delta T$ (Table 2 columns 1 and 2 ), and of $(\Delta G-\Delta T)$ and $(\Delta G+\Delta T)$ (Table 2 columns 3 and 4). Results support the predictions of the theory. On the one hand, there is no evidence that fiscal policy variables have a non-linear effect on GDP growth: the coefficients of $\Delta G^{2}$ and $\Delta T^{2}$, and $(\Delta G-\Delta T)^{2}$ and $(\Delta G+\Delta T)^{2}$ are not statistically significant. On the other hand, in the equations for $s^{*}$, the coefficients of $\Delta T^{2}$ and $(\Delta G-\Delta T)^{2}$ are significant at the $5 \%$ level and the one of $(\Delta G+\Delta T)^{2}$ is significant at the $10 \%$ level, signalling that the probability of governments' ability to solve countries fiscal imbalances depends in a non-linear way to some characteristics of the fiscal manoeuvre. Consider, as an example, the change in the primary balance. The coefficients of $(\Delta G-\Delta T)$ and $(\Delta G-\Delta T)^{2}$ are both negative and significant. Their magnitude implies that the likelihood of a successful stabilization is increasing in the improvement in the primary balance and that the maximum effect is obtained when the primary balance-to-GDP ratio improves by 5 
percentage points in one year. Note that, in the sample, there are only two cases in which the improvement in the primary balance is larger than 5 percentage points of GDP. Hence, for almost all values of $(\Delta G-\Delta T)$, larger improvements in the balance increase the likelihood of a successful fiscal contraction.

Second, I check whether the occurrence of a large fiscal adjustment matters and whether changes in public spending, taxation, the primary balance and the way in which the change in the balance is obtained have a different effect on $s^{*}$ and/or $y$ in "normal times" and during periods of large fiscal contractions. To do so, I define a dummy variable $S T A B$ equal to one if the cyclically adjusted primary balance improves by at least 1.5 percentage points of GDP relative to the previous year and zero otherwise. I include $S T A B$ and the interaction terms between $S T A B$ and $\Delta G$ and $\Delta T$ (Table 2 columns 5 and 6), or $S T A B$ and $(\Delta G-\Delta T)$ and $(\Delta G+\Delta T)$ (Table 2 columns 7 and 8 ) among the regressors of the equations estimated in Table 1, columns $5-8 .{ }^{15}$ Results of the equations for $s^{*}$ are in columns 5 and 7 of Table 2. The estimated coefficient of the variable $S T A B$ is positive and statistically significant, but the sign of the coefficients of the interaction terms between the variable $S T A B$ and $\Delta G$ and $\Delta T$ are opposite to the one of $\Delta G$ and $\Delta T$. Ceteris paribus, during periods of large fiscal adjustments (i.e. when $S T A B=1$ ), the likelihood of a success is higher, while the effect of a one percentage point increase in taxation is lower than in normal times (i.e. when $S T A B=0$ ) and the effect on $s^{*}$ of a one percentage point cut to government spending is not statistically significant (the data do not reject the linear restriction that the sum of the coefficient of $\Delta G$ and $\Delta G(S T A B)$ is zero). Overall, however, the size of the adjustment matters for its success: computing the average probability of governments' ability to solve a fiscal imbalance when $S T A B=0$ and when $S T A B=1$, the probability of a success jumps from 0.21 to 0.35 (using the coefficients in column 5) or to 0.30 (using the coefficients in column 7). As for the results of the GDP

\footnotetext{
${ }^{15}$ Theoretically, there is no reason why the probability that the government is able to reduce the debt-to-GDP ratio should respond in a non-linear fashion to large improvements in the balance, but not to large deteriorations. Empirically, however, we cannot test this assumption using the model described in section 3. Suppose we introduce among the regressors of the equation for $s^{*}$ a dummy variable similar in spirit to $S T A B$ but equal to one if the cyclically adjusted primary balance deteriorates by no less than a certain percent and zero otherwise. The latter variable perfectly predicts some observations, because, by definition, the variable $s$ is always equal to zero when the primary balance deteriorates. Hence, we cannot estimate the coefficient of a dummy variable that measures large deteriorations in the budget in our probit model. In order to avoid this technical problem, one could define the dependent variable considering only the value of the debt-to-GDP ratio in future years, without imposing any constraint on the change in the primary balance in year $t$. However, as discussed at the beginning of section 3, it is hard to interpret a change in the debt-to-GDP ratio that does not result from any discretionary improvement in the budget as a change in fiscal policy regime. Hence, this choice does not seem sensible for the purpose of this paper. Moreover, this paper follows the literature focusing on large fiscal contractions, rather than on large fiscal expansions. The working paper version of this paper also estimates, in the single equation approach, a specification including a variable that measures the effect of large deteriorations in the primary balance in the equation for GDP growth. I find no evidence that the occurrence of a large deterioration in the primary balance affects GDP growth.
} 
growth regressions (columns 6 and 8), there is no evidence that the direct effect of fiscal policy shocks on growth is different in periods of large fiscal stabilizations than in other times and that large fiscal contractions per se increase economic activity. The coefficient of the variable $S T A B$ and those of the interaction terms between $S T A B$ and the fiscal policy variables are not statistically significant. At best, in the specification in which the coefficient of $s^{e}$ is significant, the occurrence of a large fiscal contraction has a positive effect on economic activity only through its effect on agents' expectations about future fiscal policy (see, for example, columns 7 and 8 of Table 2). ${ }^{16}$ These results are largely consistent with the predictions of the labor market view and with the evidence in Alesina et al. (2002) on investment.

\subsection{Effects of changes to selected items of the government budget}

Table 3 investigates the effect of changes to the government wage bill $(\triangle C W)$, public employment $(\Delta E G)$, and labor taxes $(\triangle L A B T)$ to provide more evidence on the effect of fiscal policy through the labor market. The labor market view, in fact, suggests that these components of the budget are particularly important for economic activity through their effect on private sector's labor costs. Moreover, Table 3 also estimates a specification that includes the change to government investment $(\Delta I G)$ among the explanatory variables of the estimated equations to investigate whether the positive effect of a decrease in public spending on growth shown in Table 1 is due to a crowding-in effect that a decrease in public investment can have on private investment.

The specification in Table 3 builds on the results in Table 1. It controls for the size of the fiscal manoeuvre including the change in the primary balance as a share of GDP, $(\Delta G-\Delta T)$, only in the equation for $s^{*}$. It controls for the effect of expectations adding $s^{e}$ among the regressors of the growth equation. It includes $\Delta C W, \Delta E G$, $\triangle L A B T$, and $\triangle I G$ in both equations to check through which channels changes to fiscal policy affect growth beyond the expectation channel. Controlling for expectations, changes in the government wage bill, public employment and labor taxes have a negative and statistical significant effect on GDP growth, while changes in government investment are not statistically significant for GDP growth. These results are consistent with the predictions of the labor market view and the statistical evidence on fiscal stabilizations, which shows that episodes that relied mainly on decreases in public investment were not associated with a boom in economic activity while episodes based on large cuts to the government wage bill and welfare payments were accompanied

\footnotetext{
${ }^{16}$ If we include the dummy variable $S T A B$ among the regressors of Table 2 columns 5-8, but not the interaction terms between $S T A B$ and the fiscal policy variables, results are virtually identical to those in Table 1 columns 5-8. However, the coefficient of $S T A B$ is not statistically significant in the equations for $s^{*}$. Note also that results do not depend on the definition of a large fiscal contraction. See section 5 of the working paper version of this paper for results based on different definitions of the variable $S T A B$.
} 
by an economic expansion (see, for example, Alesina and Ardagna (1998)).

\subsection{The role of the policy mix}

Fiscal stabilizations rarely happen in isolation; they are often part of broader policy packages. Even in a standard IS-LM model, a fiscal contraction that is accompanied by an expansionary monetary policy can lead to a boom in the economy. The specifications in Tables 1 - 3 do not control for the stance of monetary policy. Suppose, for example, that the fiscal tightening is accompanied by a lax policy, or that exchange rate devaluations systematically anticipate the fiscal adjustments that turn out to be successful and expansionary. In this case, the coefficients of fiscal policy variables can be biased capturing the effect of monetary rather than fiscal policy. Previous research has been aware of this problem, but has failed to address it. This paper explicitly controls for the stance of monetary and exchange rate policies providing a further check that the conclusions reached so far are sound. I reestimate the models of Tables 3 including as regressors in the GDP growth equation lagged values of the rate of growth of M2, of the change in the short-term nominal interest rate, and of the rate of growth of the nominal exchange rate. ${ }^{17}$ As an example, Table 4 shows the specifications augmented with the rate of growth of the nominal exchange rate. Results for the other specifications are available upon request. While an increase in money growth and a decrease in the short-term nominal interest rate increase GDP growth, there is no robust evidence that changes in the nominal exchange rate have a statistical significant effect on economic activity. There is mixed evidence in the literature on the link between fiscal consolidations and exchange rate devaluations as well. Some studies present evidence that stronger devaluations anticipate some expansionary fiscal adjustments, some find the opposite result. ${ }^{18}$ This paper is not concerned with whether or not monetary policy affects the economy. What matters here is that the coefficients of fiscal policy variables do not capture the impact of monetary rather than fiscal policy. Indeed, the coefficients of fiscal policy variables and of $s^{e}$ and the t-statistics in Table 4 are very similar to those in Table 3 .

\footnotetext{
${ }^{17}$ Data availability and comparability across countries constraints the choice of the indicators of the monetary policy's stance.

${ }^{18}$ Bradley and Whelan (1997), for example, claim that the increase in export due to the devaluation of the nominal exchange rate determined the boom during the Irish stabilization in 1987-1989. Alesina and Ardagna (1998) show that devaluations are important elements of the policy package, but that devaluations alone are not sufficient to drive a boom in the economy. Alesina et al. (2002) find, instead, that on average the contribution from net export to GDP growth decreases during expansionary fiscal contractions. Hence, they find no evidence to link the boom in the economy to a surge in exports. Finally, in an empirical model that does not control for the effect of current GDP growth on the probability that the adjustment leads to a reduction of the debt-to-GDP ratio, Lambertini and Tavares (2001) find evidence that devaluations matter for the success of a fiscal contraction.
} 


\section{Sensitivity analysis}

This sections summarizes several robustness checks. Results (not shown and available upon request) support the conclusions discussed in section 4 .

First, results are robust to alternative specifications of the sample of country-years in which there is need for fiscal austerity. I estimate columns 7 and 8 of Table 1 using the following rules. First, I include in the sample only the observations for which the debt-to-GDP ratio lagged one year is greater than the average value in the country. Second, I select all those observations for which the primary spending-to-GDP ratio lagged one year is greater than the average value in the country. Finally, I consider all the observations for which the deficit as a share of GDP lagged one year is greater than the average value in the country. Compared with the estimates in Table 1, real GDP growth is not statistically significant in the equation for $s^{*}$ when countries are selected on the basis of debt and deficit's levels. The effects of agents' expectations about governments' ability to solve a fiscal imbalance and those of fiscal policy characteristics are very similar to results in Table 1.

Second, different definitions of the variable measuring governments' ability to solve countries' fiscal imbalances do not alter results shown so far. First, I define a successful fiscal stabilization as an episode in which the cyclical adjusted primary balance improves and, two year after, the debt-to-GDP ratio is at least 1.5 percentage points lower than in the year of the fiscal tightening. Second, to lose fewer observations at the end of the sample, I look at a shorter horizon. Specifically, I require that the debt-to-GDP ratio declines by at least 1 percentage point one year after the fiscal contraction. Finally, I define a successful stabilization looking not only at the dynamics of the debt-to-GDP ratio but also at the dynamics of the deficit. Thus, I define a successful stabilization as an episode in which the cyclical adjusted primary balance improves and, two years after, either the debt-to-GDP ratio is 3 percentage point lower or the deficit as a share of GDP is 1.5 percentage points lower than in the year of the fiscal tightening. The only difference relatively to the estimates in Table 1 is that real GDP growth is not statistically significant in the equation for $s^{*}$ when the second definition is used.

Finally, following Alesina and Perotti (1997) who find evidence of a hump-shaped relation between changes in labor taxation and changes in competitiveness, the paper investigates if fiscal policy has a different effect on GDP growth according to the degree of centralization of the labor market. The paper uses the index by Calmfors and Driffill (1988) and classifies countries in different groups according to their level of centralization. ${ }^{19}$ The

\footnotetext{
${ }^{19}$ Calmfors and Driffill (1988) rank Austria, Norway, Sweden, Denmark, Finland, Germany, the Netherlands, Belgium, Australia, France, United Kingdom, Italy, Japan, the United States, and Canada in descending order of centralization. Following Alesina and Perotti (1997), this paper includes Norway, Sweden, Denmark, and Finland in the group of centralized countries; Germany, the Netherlands, and Belgium
} 
paper, then, interacts the fiscal policy variables with the dummy variables for the different groups of countries. Results suggest that the negative effect of $\Delta G$ and $\Delta C W$ on economic activity does not depend on the degree of centralization of the labor market. Labor taxes, instead, have a different effect on GDP growth in different countries. Increases in labor taxes have a negative effect on GDP growth in countries with intermediate degree of centralization and in the most decentralized countries, while the effect of changes in labor taxes is not statistically significant in all other countries. Hence, the paper finds little evidence of a hump-shaped relation between the degree of centralization of the labor market and the effect of changes to fiscal policy on economic growth.

\section{Conclusions}

This paper evaluates the determinants of the different macroeconomic outcomes observed during and a few years after many episodes of fiscal consolidations in the OECD countries. The evidence suggests that the probability that tight fiscal policies lead to a decrease in the debt-to-GDP ratio increases the larger the cut in the deficit. As for the effect of changes to fiscal policy on GDP growth, the paper finds that the composition of fiscal policy is a crucial element for growth and that the labor market is an important channel for the transmission of fiscal policy shocks. In fact, controlling for the impact that fiscal policy changes have on GDP growth through their effects on expectations, GDP growth is higher the larger the decrease of public spending, and especially of the government wage bill. Agents' expectations about governments' ability to solve countries' fiscal imbalances are, instead, statistically significant only in some specifications of the growth equation. Hence, the evidence on the effect of fiscal policy on economic activity through this channel is mixed. Finally, the paper shows that successful and expansionary fiscal contractions are not the result of expansionary monetary policies or of exchange rate devaluations. The paper does not address some interesting issues such as the behavior of interest rates and financial markets around the time of the fiscal adjustments and the interaction between fiscal policies, income policies, structural reforms of the labor market, and privatizations. These topics deserve further investigation.

in the group of countries with an intermediate degree of centralization; Canada, the United States, Japan, Italy, United Kingdom, France, and Australia in the group of the decentralized countries. Greece, Ireland and Spain are not classified in Alesina and Perotti (1997) and are in as a separate group in this paper. 


\section{A Data Appendix}

Economic data are from the OECD Economic Outlook no.72. Political data up to 1990 and for all countries except Greece and Spain are from Budge, Keman and Woldendrop (1993). Data for Greece and Spain, as well as for the period 1990-2002 are from the Political Handbook of the World.

- Debt $=$ government gross debt.

- Primary expenditure $=$ transfers + government consumption + public investment + subsidies.

- Government wages = wage government consumption.

- Revenue $=$ direct taxes on households + direct taxes on business + indirect taxes + social security contributions received by the government + other current transfers received by the government.

- Labor taxes $=$ direct taxes on households + social security contributions.

- Tran* = cyclically adjusted transfer as a share of GDP as in Alesina and Perotti (1995).

- $\mathrm{Rev}^{*}=$ cyclically adjusted revenue as a share of GDP as in Alesina and Perotti (1995).

- Primary cyclically adjusted balance/GDP $=($ Tran* $)+(($ government consumption + public investment + subsidiesgovernment consumption of fixed capital-net capital transfers received by the government $\left.\left.{ }^{20}\right) / \mathrm{GDP}\right)$-(Rev*). After 1970, other payments made and received by the governments, (variables YPEPG and YPERG) are also considered in the definition of the primary deficit and interest payments are excluded.

- $\Delta G=$ change in cyclically adjusted primary spending as a share of GDP.

- $\Delta T=$ change in cyclically adjusted government revenue as a share of GDP.

- $\Delta E G=$ percentage change in public employment as a share of total employment.

- $\triangle C W=$ change in government wage bill as a share of GDP.

- $\triangle L A B T=$ change in cyclically adjusted labor taxes' revenue as a share of GDP.

\footnotetext{
${ }^{20}$ In each year, the following data are missing: a) government consumption of fixed capital (Cfgk) for France, United Kingdom and Portugal; b) net capital transfer received by the government (Ktrrg) for Norway; c) government consumption of fixed capital and net capital transfer received by the government for Greece. For these countries, the variables corresponding to the missing data are not included in the equation for the primary cyclically adjusted deficit.
} 
- $S T A B=1$ if the cyclically adjusted primary balance improves by at least 1.5 percentage points of GDP relative to the previous year and zero otherwise.

- Growth = growth rate of real per capita GDP.

- Growth $(G 7)=$ average growth rate of real per capita GDP (with GDP weights) of the seven major industrial countries.

- $\triangle E X C H=$ rate of change of the nominal effective exchange rate. A minus sign corresponds to a devaluation of the currency.

- $\% \Delta M 2=$ rate of growth of $\mathrm{M} 2$.

- Interest rate $=$ Short term interest rate.

- $\Delta$ Interest rate $=$ Short term interest rate $(\mathrm{t})$-Short term interest rate $(\mathrm{t}-1)$.

- Majority $=1$ if the government in office during the year is a majoritarian government. The classification is from Budge, Keman and Woldendrop (1993). If there are changes of government during the year, the type of the government is determined by the government in office for the highest number of months.

- Left $=1$ if the government in office during the year is a left government. The classification is from Budge, Keman and Woldendrop (1993). If there are changes of government during the year, the type of the government is determined by the government in office for the highest number of months.

- Centre $=1$ if the government in office during the year is a centre government. The classification is from Budge, Keman and Woldendrop (1993). If there are changes of government during the year, the type of the government is determined by the government in office for the highest number of months. 


\section{References}

[1] Alesina A., and S. Ardagna, 1998, Tales of Fiscal Adjustments, Economic Policy, October 1998, 489-545.

[2] Alesina A., S. Ardagna, R. Perotti, and F. Schiantarelli, 2002, Fiscal Policy, Profits, and Investment, American Economic Review, vol. 92, no. 3, June 2002, 571-589.

[3] Alesina A., R. Perotti, and J. Tavares, 1998, The Political Economy of Fiscal Adjustments, Brookings Papers on Economic Activity, Spring 1998.

[4] Alesina A., and R. Perotti, 1997, The Welfare State and Competitiveness, American Economic Review, 1997, 87, 921-939.

[5] Alesina A., and R. Perotti, 1995, Fiscal Expansions and Adjustments in OECD Countries, Economic Policy, n.21, 207-247.

[6] Amemiya T., 1978, The Estimation of a Simultaneous Equation Generalized Probit Model, Econometrica, vol.46, 1193-1205.

[7] Ardagna S., 2002, Fiscal Stabilizations: When Do They Work and Why, Wellesley College, working paper 2002-08, July 2002.

[8] Ardagna S., 2002, Fiscal Policy in Unionized Labor Markets, Wellesley College, working paper 2002-07, January 162002.

[9] Baxter M., and R. King, 1993, Fiscal Policy in General Equilibrium, American Economic Review, June, 83, 315-334.

[10] Bertola G., and Drazen, Allen, 1993, Trigger Points and Budget Cuts: Explaining the Effects of Fiscal Austerity, American Economic Review, March 1993, 11-26.

[11] Blanchard O., 1993, Suggestion for a New Set of Fiscal Indicators, OECD Working paper.

[12] Blanchard O., 1990, Comment on Giavazzi and Pagano, NBER Macroeconomics Annual, MIT Press, Cambridge, MA, 1990.

[13] Bradley J., and K. Whelan, 1997, The Irish Expansionary Fiscal Contraction: A Tale From One Small European Economy, Economic Modelling, 14, 175-201. 
[14] Budge I., H. Keman, and J. Woldendrop, 1993, Political Data 1945-1990, European Journal of Political Research, special issue, 24-1.

[15] Calmfors L., and J. Driffill, 1988, Bargaining Structure, Corporatism and Macroeconomic Performance, Economic Policy, April 1988, vol. 6, 13-62.

[16] Cukierman A., and M. Tommasi, 1998, When Does It Take a Nixon to Go to China?, American Economic Review, vol. 88, n. 1, 180-197.

[17] Daveri F., and G. Tabellini, 2000, Unemployment, Growth and Taxation in Industrial Countries, Economic Policy, April 2000, 47-88.

[18] Feldstein M., 1982, Government Deficits and Aggregate Demand, Journal of Monetary Economics, 9(1), January $1982,1-20$.

[19] Giavazzi, F., T. Jappelli, and M. Pagano, 2000, Searching for Non-Linear Effects of Fiscal Policy: Evidence from Industrial and Developing Countries, European Economic Review, 2000, vol. 44, n.7, 1259-1289.

[20] Giavazzi F., and M. Pagano, 1996, Non-Keynesian Effects of Fiscal Policy Changes: International Evidence and the Swedish Experience, Swedish Economic Policy Review, vol. 3, n.1, Spring, 67-112.

[21] Giavazzi F., and M. Pagano, 1990, Can Severe Fiscal Contractions Be Expansionary? Tales of Two Small European Countries, NBER Macroeconomics Annual, MIT Press, (Cambridge, MA), 1990, 95-122.

[22] Kontopoulos Y., and R. Perotti, 2002, Fragmented Fiscal Policy, Journal of Public Economics, Vol. 86 (2), 191-222.

[23] Lambertini L., and J. Tavares, 2001, Exchange Rates and Fiscal Adjustments: Evidence from the ECD and Implications for EMU.

[24] Londregan J., and K. Poole, 1990, Poverty, the Coup Trap, and the Seizure of Executive Power, World Politics, 42, 151-183.

[25] Ludvigson S., 1996, The Macroeconomic Effects of Government Debt in a Stochastic Growth Model, Journal of Monetary Economics, 38, 25-45.

[26] Maffezzoli M., 2001, Non-Walrasian Labor Markets and Real Business Cycles, Review of Economic Dynamics, Vol. 4 (4), 860-92. 
[27] McDermott J., and R. Wescott, 1996, An Empirical Analysis of Fiscal Adjustments, IMF Staff papers, vol. 43, n. $4,723-753$.

[28] Miller M., R. Skidelsky, and P. Weller, 1990, Fear of Deficit Financing - Is It Rational ?, in R. Dornbusch and M. Draghi (eds.), Public Debt Management: Theory and History, Cambridge University Press.

[29] Murphy K., and Topel R., 1985, Estimation and Inference in Two Steps Econometric Models, Journal of Business, Economics and Statistics, 1985, 3, 370-79.

[30] Newey W., 1987, Efficient Estimation of Limited Dependent Variable models with Endogenous Explanatory Variables, Journal of Econometrics, vol. 36, 231-250.

[31] Obstfeld M., 1998, Comment on Alesina, Perotti and Tavares, Brookings Papers on Economic Activity, Spring 1998.

[32] OECD, Economic Outlook, and Surveys, various years.

[33] Olivei G., 1999, Fiscal Retrenchments and The Level of Economic Activity, Federal Reserve Bank of Boston, Working Paper: 99/03.

[34] Pagan A., 1986, Two Stage and Related Estimators and Their Applications, Review of Economic Studies, $517-538$.

[35] Pagan, A., 1984, Econometric Issues in the Analysis of Regressions with Generated Regressors, International Economic Review, vol. 25, n.1, 1984, 221-247.

[36] Perotti, Roberto, 1999, Fiscal Policy When Things are Going Badly, Quarterly Journal of Economics, 114, November 1999, 1399-1436.

[37] Political Handbook of the World, various years, McGraw-Hill, New York.

[38] Sutherland, Alan, 1997, Fiscal Crises and Aggregate Demand: Can High Public Debt Reverse the Effects of Fiscal Policy?, Journal of Public Economics 65, 1997, 147-162. 
Table 1: Success and growth: basic specifications

\begin{tabular}{|c|c|c|c|c|c|c|c|c|}
\hline \multirow{3}{*}{ Dependent variables } & \multicolumn{4}{|c|}{ Single Equation Approach } & \multicolumn{4}{|c|}{ Simultaneous Equation Approach } \\
\hline & $\mathbf{S}^{*}$ & Growth & $\mathbf{S}^{*}$ & Growth & $\mathbf{S}^{*}$ & Growth & $\mathbf{S}^{*}$ & Growth \\
\hline & (1) & (2) & (3) & (4) & (5) & (6) & (7) & (8) \\
\hline$S^{e}$ & & $\begin{array}{l}0.002 \\
(1.03)\end{array}$ & & $\begin{array}{l}0.003 \\
(4.26)\end{array}$ & & $\begin{array}{l}0.002 \\
(1.04)\end{array}$ & & $\begin{array}{l}0.003 \\
(3.63)\end{array}$ \\
\hline Growth & & & & & $\begin{array}{l}46.56 \\
(2.59)\end{array}$ & & $\begin{array}{l}45.98 \\
(2.56)\end{array}$ & \\
\hline$\Delta \mathrm{G}$ & $\begin{array}{l}-56.94 \\
(-5.15)\end{array}$ & $\begin{array}{c}-0.47 \\
(-3.08)\end{array}$ & & & $\begin{array}{l}-30.98 \\
(-2.07)\end{array}$ & $\begin{array}{c}-0.46 \\
(-3.03)\end{array}$ & & \\
\hline$\Delta \mathrm{T}$ & $\begin{array}{l}80.52 \\
(5.72)\end{array}$ & $\begin{array}{c}-0.30 \\
(-1.46)\end{array}$ & & & $\begin{array}{l}83.31 \\
(5.57)\end{array}$ & $\begin{array}{c}-0.30 \\
(-1.54)\end{array}$ & & \\
\hline$(\Delta \mathrm{G}-\Delta \mathrm{T})$ & & & $\begin{array}{l}-68.73 \\
(-6.51)\end{array}$ & & & & $\begin{array}{l}-58.26 \\
(-5.35)\end{array}$ & \\
\hline$(\Delta \mathrm{G}+\Delta \mathrm{T})$ & & & $\begin{array}{l}11.79 \\
(1.69)\end{array}$ & $\begin{array}{c}-0.40 \\
(-7.31)\end{array}$ & & & $\begin{array}{l}26.08 \\
(2.61)\end{array}$ & $\begin{array}{c}-0.39 \\
(-7.29)\end{array}$ \\
\hline Growth $(\mathrm{t}-1)$ & $\begin{array}{l}18.39 \\
(2.74)\end{array}$ & $\begin{array}{c}0.35 \\
(5.08)\end{array}$ & $\begin{array}{l}18.39 \\
(2.74)\end{array}$ & $\begin{array}{c}0.33 \\
(5.60)\end{array}$ & & $\begin{array}{c}0.35 \\
(5.30)\end{array}$ & & $\begin{array}{c}0.33 \\
(5.86)\end{array}$ \\
\hline Growth G7 (t-1) & & $\begin{array}{c}0.01 \\
(0.16)\end{array}$ & & $\begin{array}{l}0.014 \\
(0.20)\end{array}$ & & $\begin{array}{c}0.01 \\
(0.19)\end{array}$ & & $\begin{array}{c}0.01 \\
(0.23)\end{array}$ \\
\hline Deficit/GDP (t-1) & $\begin{array}{l}-15.15 \\
(-3.24)\end{array}$ & $\begin{array}{l}-0.007 \\
(-0.15)\end{array}$ & $\begin{array}{l}-15.15 \\
(-3.24)\end{array}$ & $\begin{array}{l}0.011 \\
(0.39)\end{array}$ & $\begin{array}{l}-12.78 \\
(-2.53)\end{array}$ & $\begin{array}{l}-0.006 \\
(-0.14)\end{array}$ & $\begin{array}{l}-12.99 \\
(-2.59)\end{array}$ & $\begin{array}{c}0.01 \\
(0.37)\end{array}$ \\
\hline Debt/GDP (t-1) & $\begin{array}{c}7.46 \\
(5.81)\end{array}$ & $\begin{array}{l}-0.016 \\
(-0.85)\end{array}$ & $\begin{array}{c}7.46 \\
(5.81)\end{array}$ & $\begin{array}{l}-0.024 \\
(-2.60)\end{array}$ & $\begin{array}{c}7.25 \\
(5.53)\end{array}$ & $\begin{array}{l}-0.016 \\
(-0.90)\end{array}$ & $\begin{array}{c}7.22 \\
(5.57)\end{array}$ & $\begin{array}{c}-0.03 \\
(-2.61)\end{array}$ \\
\hline Left government & $\begin{array}{c}0.84 \\
(2.72)\end{array}$ & & $\begin{array}{c}0.84 \\
(2.72)\end{array}$ & & $\begin{array}{c}0.76 \\
(2.48)\end{array}$ & & $\begin{array}{c}0.71 \\
(2.75)\end{array}$ & \\
\hline Centre government & $\begin{array}{c}-0.53 \\
(-1.14)\end{array}$ & & $\begin{array}{c}-0.53 \\
(-1.14)\end{array}$ & & $\begin{array}{c}-0.39 \\
(-0.89)\end{array}$ & & $\begin{array}{c}-0.29 \\
(-0.80)\end{array}$ & \\
\hline Majority government & $\begin{array}{c}-0.21 \\
(-0.46) \\
\end{array}$ & & $\begin{array}{c}-0.21 \\
(-0.46) \\
\end{array}$ & & $\begin{array}{c}-0.19 \\
(-0.44) \\
\end{array}$ & & $\begin{array}{c}-0.16 \\
(-0.44) \\
\end{array}$ & \\
\hline $\begin{array}{l}\text { N. of observations } \\
\chi^{2} \text { test of over. restrictions } \\
\text { p-value }\end{array}$ & 413 & 413 & 413 & 413 & & & & \\
\hline
\end{tabular}

\section{Tests}

\begin{tabular}{|c|c|cc|}
\hline \hline Column & Null Hypothesis & Test statistics & p-value \\
& & & 0.09 \\
$(1)$ & $\mathrm{H}_{0}: \Delta \mathrm{G}+\Delta \mathrm{T}=0$ & 1.69 & 0.00 \\
$(1)$ & $\mathrm{H}_{0}: \Delta \mathrm{G}-\Delta \mathrm{T}=0$ & -6.51 & 0.00 \\
$(2)$ & $\mathrm{H}_{0}: \Delta \mathrm{G}+\Delta \mathrm{T}=0$ & -6.57 & 0.61 \\
$(2)$ & $\mathrm{H}_{0}: \Delta \mathrm{G}-\Delta \mathrm{T}=0$ & -0.50 & 0.009 \\
$(5)$ & $\mathrm{H}_{0}: \Delta \mathrm{G}+\Delta \mathrm{T}=0$ & 2.62 & 0.00 \\
$(5)$ & $\mathrm{H}_{0}: \Delta \mathrm{G}-\Delta \mathrm{T}=0$ & -5.13 & 0.00 \\
$(6)$ & $\mathrm{H}_{0}: \Delta \mathrm{G}+\Delta \mathrm{T}=0$ & -6.91 & 0.62 \\
$(6)$ & $\mathrm{H}_{0}: \Delta \mathrm{G}-\Delta \mathrm{T}=0$ & -0.49 & \\
\hline
\end{tabular}

Notes: Probit specification in columns 1 and 3. OLS regressions in columns 2 and 4. Estimation by AGLS technique in columns 5-8. Dependent variables: Success $\left(\mathrm{S}^{*}\right)$ in columns 1, 3, 5, 7 and real per capita GDP growth rate (Growth) in columns 2, 4, 6, 8. $\mathrm{S}^{\mathrm{e}}=$ variable measuring agents' expectations about $\mathrm{S}^{*} . \Delta \mathrm{G}=$ change in cyclically adjusted primary spending as a share of GDP. $\Delta \mathrm{T}=$ change in cyclically adjusted government revenue as a share of GDP. Growth G7 = average real per capita GDP growth of the G7 countries. Deficit/GDP = government deficit as a share of GDP. Debt/GDP $=$ public debt as a share of GDP. Left $=1$ if government in office is left oriented, and zero otherwise. Centre $=1$ if government in office is center oriented, and zero otherwise. Majority $=1$ if a single party has the majority in the Parliament, and zero otherwise. See also the Data Appendix for variables' definitions. Country fixed effects are included. t-statistics in parenthesis. 
Table 2: Success, growth, and nonlinearities

\begin{tabular}{|c|c|c|c|c|c|c|c|c|}
\hline \multirow{3}{*}{ Dependent variables } & \multicolumn{8}{|c|}{ Simultaneous Equation Approach } \\
\hline & $\mathbf{S}^{*}$ & Growth & $\mathbf{S}^{*}$ & Growth & $\mathbf{S}^{*}$ & Growth & $\mathbf{S}^{*}$ & Growth \\
\hline & (1) & (2) & (3) & (4) & (5) & (6) & (7) & (8) \\
\hline$S^{e}$ & & $\begin{array}{l}0.003 \\
(1.31)\end{array}$ & & $\begin{array}{l}0.003 \\
(3.12)\end{array}$ & & $\begin{array}{l}0.003 \\
(1.20)\end{array}$ & & $\begin{array}{l}0.003 \\
(3.72)\end{array}$ \\
\hline Growth & $\begin{array}{l}37.41 \\
(1.94)\end{array}$ & & $\begin{array}{l}35.10 \\
(1.82)\end{array}$ & & $\begin{array}{l}33.50 \\
(1.74)\end{array}$ & & $\begin{array}{l}36.28 \\
(1.91)\end{array}$ & \\
\hline 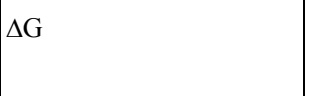 & $\begin{array}{l}-62.44 \\
(-3.33)\end{array}$ & $\begin{array}{c}-0.34 \\
(-1.82)\end{array}$ & & & $\begin{array}{l}-77.13 \\
(-3.11)\end{array}$ & $\begin{array}{c}-0.44 \\
(-1.80)\end{array}$ & & \\
\hline$\Delta \mathrm{T}$ & $\begin{array}{r}105.48 \\
(5.31)\end{array}$ & $\begin{array}{c}-0.38 \\
(-1.70)\end{array}$ & & & $\begin{array}{l}139.1 \\
(5.66)\end{array}$ & $\begin{array}{l}-0.40 \\
(-1.20)\end{array}$ & & \\
\hline$(\Delta \mathrm{G})^{2}$ & $\begin{array}{l}-881.93 \\
(-1.28)\end{array}$ & $\begin{array}{l}-4.56 \\
(-1.25)\end{array}$ & & & & & & \\
\hline$(\Delta \mathrm{T})^{2}$ & $\begin{array}{l}-2227.1 \\
(-2.56)\end{array}$ & $\begin{array}{c}4.94 \\
(0.75)\end{array}$ & & & & & & \\
\hline$(\Delta \mathrm{G}-\Delta \mathrm{T})$ & & & $\begin{array}{l}-84.12 \\
(-5.62)\end{array}$ & & & & $\begin{array}{l}-98.16 \\
(-4.92)\end{array}$ & \\
\hline$(\Delta \mathrm{G}+\Delta \mathrm{T})$ & & & $\begin{array}{l}15.64 \\
(1.37)\end{array}$ & $\begin{array}{c}-0.34 \\
(-5.66)\end{array}$ & & & $\begin{array}{l}30.90 \\
(2.66)\end{array}$ & $\begin{array}{c}-0.42 \\
(-7.42)\end{array}$ \\
\hline$(\Delta \mathrm{G}-\Delta \mathrm{T})^{2}$ & & & $\begin{array}{l}-824.7 \\
(-3.85)\end{array}$ & & & & & \\
\hline$(\Delta \mathrm{G}+\Delta \mathrm{T})^{2}$ & & & $\begin{array}{l}-681.6 \\
(-1.81)\end{array}$ & $\begin{array}{c}0.10 \\
(0.04)\end{array}$ & & & & \\
\hline$(\Delta \mathrm{G})(\mathrm{STAB})$ & & & & & $\begin{array}{l}82.20 \\
(2.50)\end{array}$ & $\begin{array}{c}0.15 \\
(0.47)\end{array}$ & & \\
\hline$(\Delta \mathrm{T})(\mathrm{STAB})$ & & & & & $\begin{array}{l}-129.33 \\
(-3.77)\end{array}$ & $\begin{array}{c}0.20 \\
(0.51)\end{array}$ & & \\
\hline$(\Delta \mathrm{G}-\Delta \mathrm{T})(\mathrm{STAB})$ & & & & & & & $\begin{array}{l}85.91 \\
(3.20)\end{array}$ & \\
\hline$(\Delta \mathrm{G}+\Delta \mathrm{T})(\mathrm{STAB})$ & & & & & & & $\begin{array}{l}-23.45 \\
(-1.47)\end{array}$ & $\begin{array}{c}0.17 \\
(1.32)\end{array}$ \\
\hline STAB & & & & & $\begin{array}{c}1.42 \\
(2.50)\end{array}$ & $\begin{array}{l}-0.002 \\
(-0.40)\end{array}$ & $\begin{array}{c}1.10 \\
(2.01)\end{array}$ & $\begin{array}{l}-0.001 \\
(-0.59)\end{array}$ \\
\hline N. of observations & & & & & & & & \\
\hline $\begin{array}{|lll|}\chi^{2} \quad \text { test } & \text { of } & \text { over. } \\
\text { restrictions } & & \\
\text { p-value } & & \\
\end{array}$ & & & & & & & & \\
\hline
\end{tabular}

Notes: Simultaneous equations approach. Estimation by AGLS technique. Dependent variables: Success $\left(\mathrm{S}^{*}\right)$ and real per capita GDP growth rate (Growth). $\mathrm{S}^{\mathrm{e}}$ variable measuring agents' expectations about $\mathrm{S}^{*} . \Delta \mathrm{G}=$ change in cyclically adjusted primary spending as a share of GDP. $\Delta \mathrm{T}=$ change in cyclically adjusted government revenue as a share of GDP. STAB $=1$ if the cyclically adjusted primary balance improves by at least 1.5 percentage points of GDP relative to the previous year and zero otherwise. Other regressors included in columns 1, 3, 5, 7 are: Deficit/GDP $(\mathrm{t}-1)$, Debt/GDP(t-1), Left, Centre, Majority. Other regressors included in columns 2, 4, 5, 8 are: Deficit/GDP (t-1), Debt/GDP(t-1), Growth (t-1), Growth G7 (t-1). See also the Data Appendix. Country fixed effects are included in all columns. t-statistics in parenthesis. 
Table 3: Success, growth and fiscal policy composition

\begin{tabular}{|c|c|c|c|c|c|c|c|c|}
\hline \multirow{3}{*}{ Dependent variables } & \multicolumn{8}{|c|}{ Simultaneous Equation Approach } \\
\hline & $\mathbf{S}^{*}$ & Growth & $\mathbf{S}^{*}$ & Growth & $\mathbf{S}^{*}$ & Growth & $\mathbf{S}^{*}$ & Growth \\
\hline & (1) & (2) & (3) & (4) & $(5)$ & (6) & (7) & $(8)$ \\
\hline$S^{e}$ & & $\begin{array}{l}0.004 \\
(3.89)\end{array}$ & & $\begin{array}{l}0.001 \\
(1.52)\end{array}$ & & $\begin{array}{l}0.004 \\
(4.19)\end{array}$ & & $\begin{array}{l}0.005 \\
(4.45)\end{array}$ \\
\hline Growth & $\begin{array}{l}69.37 \\
(2.12)\end{array}$ & & $\begin{array}{l}57.31 \\
(2.44)\end{array}$ & & $\begin{array}{l}43.47 \\
(2.10)\end{array}$ & & $\begin{array}{l}46.17 \\
(2.48)\end{array}$ & \\
\hline$(\Delta \mathrm{G}-\Delta \mathrm{T})$ & $\begin{array}{l}-48.17 \\
(-3.98)\end{array}$ & & $\begin{array}{l}-58.21 \\
(-5.41)\end{array}$ & & $\begin{array}{l}-56.67 \\
(-4.64)\end{array}$ & & $\begin{array}{l}-50.61 \\
(-4.35)\end{array}$ & \\
\hline$\Delta \mathrm{EG}$ & $\begin{array}{l}21.22 \\
(1.50)\end{array}$ & $\begin{array}{c}-0.30 \\
(-6.26)\end{array}$ & & & & & & \\
\hline$\Delta \mathrm{CW}$ & & & $\begin{array}{l}110.0 \\
(1.66)\end{array}$ & $\begin{array}{c}-2.15 \\
(-9.31)\end{array}$ & & & & \\
\hline$\Delta \mathrm{IG}$ & & & & & $\begin{array}{l}75.68 \\
(1.68)\end{array}$ & $\begin{array}{c}-0.34 \\
(-1.05)\end{array}$ & & \\
\hline$\Delta \mathrm{LABT}$ & & & & & & & $\begin{array}{l}15.53 \\
(0.97)\end{array}$ & $\begin{array}{c}-0.36 \\
(-2.83)\end{array}$ \\
\hline Growth (t-1) & & $\begin{array}{c}0.16 \\
(3.10)\end{array}$ & & $\begin{array}{c}0.28 \\
(5.60)\end{array}$ & & $\begin{array}{c}0.26 \\
(4.33)\end{array}$ & & $\begin{array}{c}0.27 \\
(4.44)\end{array}$ \\
\hline Growth G7 (t-1) & & $\begin{array}{c}0.06 \\
(1.51)\end{array}$ & & $\begin{array}{l}0.002 \\
(0.03)\end{array}$ & & $\begin{array}{c}0.04 \\
(0.79)\end{array}$ & & $\begin{array}{c}0.03 \\
(0.65)\end{array}$ \\
\hline Deficit/GDP (t-1) & $\begin{array}{l}-13.60 \\
(-2.66)\end{array}$ & $\begin{array}{c}0.03 \\
(1.09)\end{array}$ & $\begin{array}{l}-12.16 \\
(-2.25)\end{array}$ & $\begin{array}{c}-0.04 \\
(-1.51)\end{array}$ & $\begin{array}{l}-12.48 \\
(-2.44)\end{array}$ & $\begin{array}{c}0.02 \\
(0.67)\end{array}$ & $\begin{array}{l}-14.07 \\
(-2.81)\end{array}$ & $\begin{array}{c}0.04 \\
(1.23)\end{array}$ \\
\hline Debt/GDP (t-1) & $\begin{array}{c}7.67 \\
(5.10)\end{array}$ & $\begin{array}{l}-0.034 \\
(-3.74)\end{array}$ & $\begin{array}{c}7.43 \\
(5.55)\end{array}$ & $\begin{array}{c}-0.01 \\
(-1.52)\end{array}$ & $\begin{array}{c}7.21 \\
(5.48)\end{array}$ & $\begin{array}{c}-0.03 \\
(-2.58)\end{array}$ & $\begin{array}{c}7.01 \\
(5.49)\end{array}$ & $\begin{array}{c}-0.03 \\
(-2.95)\end{array}$ \\
\hline Left government & $\begin{array}{c}0.70 \\
(2.30)\end{array}$ & & $\begin{array}{c}0.76 \\
(2.60)\end{array}$ & & $\begin{array}{c}0.64 \\
(2.69)\end{array}$ & & $\begin{array}{c}0.56 \\
(2.61)\end{array}$ & \\
\hline Centre government & $\begin{array}{c}-0.22 \\
(-0.64)\end{array}$ & & $\begin{array}{c}-0.44 \\
(-1.00)\end{array}$ & & $\begin{array}{c}-0.22 \\
(-0.69)\end{array}$ & & $\begin{array}{c}-0.24 \\
(-0.85)\end{array}$ & \\
\hline Majority government & $\begin{array}{c}-0.20 \\
(-0.57) \\
\end{array}$ & & $\begin{array}{c}-0.09 \\
(-0.21) \\
\end{array}$ & & $\begin{array}{c}-0.11 \\
(-0.33)\end{array}$ & & $\begin{array}{c}-0.09 \\
(-0.34)\end{array}$ & \\
\hline $\begin{array}{l}\text { N. of observations } \\
\chi^{2} \text { test of over. restrictions } \\
\text { p-value }\end{array}$ & & & & & & & & \\
\hline
\end{tabular}

Notes: Simultaneous equations approach. Estimation by AGLS technique. Dependent variables: Success $\left(\mathrm{S}^{*}\right)$ and real per capita GDP growth rate (Growth). $\mathrm{S}^{\mathrm{e}}=$ variable measuring agents' expectations about $\mathrm{S}^{*} . \Delta \mathrm{G}=$ change in cyclically adjusted primary spending as a share of GDP. $\Delta \mathrm{T}=$ change in cyclically adjusted government revenue as a share of GDP. $\triangle \mathrm{EG}=$ percentage change in public employment. $\Delta \mathrm{CW}=\mathrm{change}$ in government wage bill as a share of GDP. $\triangle \mathrm{LABT}=$ change in cyclically adjusted labor taxes' revenue as a share of GDP. Growth G7 $=$ average real per capita GDP growth of the G7 countries. Deficit/GDP = government deficit as a share of GDP. Debt/GDP $=$ public debt as a share of GDP. Left $=1$ if government in office is left oriented, and zero otherwise. Centre $=1$ if government in office is center oriented, and zero otherwise. Majority $=1$ if a single party has the majority in the Parliament, and zero otherwise. See also the Data Appendix. Country fixed effects are included. t-statistics in parenthesis. 
Table 4: Success, growth and the policy-mix

\begin{tabular}{|c|c|c|c|c|c|c|c|c|c|c|}
\hline \multirow{3}{*}{ Dependent variables } & \multicolumn{10}{|c|}{ Simultaneous Equation Approach } \\
\hline & $\mathbf{S}^{*}$ & Growth & $\mathbf{S}^{*}$ & Growth & $\mathbf{S}^{*}$ & Growth & $\mathbf{S}^{*}$ & Growth & $\mathbf{S}^{*}$ & Growth \\
\hline & (1) & (2) & (3) & (4) & (5) & (6) & (7) & (8) & (9) & (10) \\
\hline$S^{e}$ & & $\begin{array}{l}0.003 \\
(3.59)\end{array}$ & & $\begin{array}{l}0.004 \\
(3.93)\end{array}$ & & $\begin{array}{l}0.001 \\
(1.36)\end{array}$ & & $\begin{array}{l}0.004 \\
(4.17)\end{array}$ & & $\begin{array}{l}0.005 \\
(4.52)\end{array}$ \\
\hline Growth & $\begin{array}{l}47.21 \\
(2.67)\end{array}$ & & $\begin{array}{l}69.12 \\
(2.13)\end{array}$ & & $\begin{array}{l}61.11 \\
(2.68)\end{array}$ & & $\begin{array}{l}41.75 \\
(2.02)\end{array}$ & & $\begin{array}{l}45.62 \\
(2.45)\end{array}$ & \\
\hline$(\Delta \mathrm{G}-\Delta \mathrm{T})$ & $\begin{array}{l}-57.67 \\
(-5.28)\end{array}$ & & $\begin{array}{l}-47.45 \\
(-3.93)\end{array}$ & & $\begin{array}{l}-58.03 \\
(-5.35)\end{array}$ & & $\begin{array}{l}-56.69 \\
(-4.64)\end{array}$ & & $\begin{array}{l}-50.07 \\
(-4.29)\end{array}$ & \\
\hline$(\Delta \mathrm{G}+\Delta \mathrm{T})$ & $\begin{array}{l}26.39 \\
(2.69)\end{array}$ & $\begin{array}{c}-0.40 \\
(-7.43)\end{array}$ & & & & & & & & \\
\hline$\Delta \mathrm{EG}$ & & & $\begin{array}{l}21.21 \\
(1.52)\end{array}$ & $\begin{array}{c}-0.30 \\
(-6.28)\end{array}$ & & & & & & \\
\hline$\Delta \mathrm{CW}$ & & & & & $\begin{array}{l}118.9 \\
(1.84)\end{array}$ & $\begin{array}{c}-2.24 \\
(-9.38)\end{array}$ & & & & \\
\hline$\Delta \mathrm{IG}$ & & & & & & & $\begin{array}{l}75.26 \\
(1.68)\end{array}$ & $\begin{array}{c}-0.34 \\
(-1.05)\end{array}$ & & \\
\hline$\Delta \mathrm{LABT}$ & & & & & & & & & $\begin{array}{l}15.47 \\
(0.97)\end{array}$ & $\begin{array}{c}-0.37 \\
(-2.89)\end{array}$ \\
\hline Growth (t-1) & & $\begin{array}{c}0.33 \\
(5.86)\end{array}$ & & $\begin{array}{c}0.16 \\
(3.04)\end{array}$ & & $\begin{array}{c}0.28 \\
(5.57)\end{array}$ & & $\begin{array}{c}0.27 \\
(4.36)\end{array}$ & & $\begin{array}{c}0.27 \\
(4.44)\end{array}$ \\
\hline Growth G7 (t-1) & & $\begin{array}{c}0.01 \\
(0.16)\end{array}$ & & $\begin{array}{c}0.06 \\
(1.13)\end{array}$ & & $\begin{array}{c}-0.0004 \\
(-0.06)\end{array}$ & & $\begin{array}{c}0.04 \\
(0.80)\end{array}$ & & $\begin{array}{c}0.03 \\
(0.64)\end{array}$ \\
\hline Deficit/GDP (t-1) & $\begin{array}{l}-12.76 \\
(-2.56)\end{array}$ & $\begin{array}{l}0.013 \\
(0.42)\end{array}$ & $\begin{array}{l}-13.36 \\
(-2.63)\end{array}$ & $\begin{array}{c}0.03 \\
(1.10)\end{array}$ & $\begin{array}{l}-11.66 \\
(-2.17)\end{array}$ & $\begin{array}{c}-0.04 \\
(-1.52)\end{array}$ & $\begin{array}{l}-12.48 \\
(-2.44)\end{array}$ & $\begin{array}{c}0.02 \\
(0.67)\end{array}$ & $\begin{array}{l}-14.07 \\
(-2.81)\end{array}$ & $\begin{array}{c}0.04 \\
(1.25)\end{array}$ \\
\hline Debt/GDP (t-1) & $\begin{array}{c}7.21 \\
(5.57)\end{array}$ & $\begin{array}{l}-0.024 \\
(-2.76)\end{array}$ & $\begin{array}{c}7.60 \\
(5.10)\end{array}$ & $\begin{array}{c}-0.03 \\
(-3.83)\end{array}$ & $\begin{array}{c}7.43 \\
(5.55)\end{array}$ & $\begin{array}{c}-0.01 \\
(-1.68)\end{array}$ & $\begin{array}{c}7.21 \\
(5.46)\end{array}$ & $\begin{array}{c}-0.03 \\
(-2.58)\end{array}$ & $\begin{array}{c}7.01 \\
(5.49)\end{array}$ & $\begin{array}{c}-0.03 \\
(-2.95)\end{array}$ \\
\hline Left government & $\begin{array}{c}0.71 \\
(2.74)\end{array}$ & & $\begin{array}{c}0.68 \\
(2.24)\end{array}$ & & $\begin{array}{c}0.76 \\
(2.57)\end{array}$ & & $\begin{array}{c}0.63 \\
(2.67)\end{array}$ & & $\begin{array}{c}0.56 \\
(2.61)\end{array}$ & \\
\hline Centre government & $\begin{array}{c}-0.28 \\
(-0.77)\end{array}$ & & $\begin{array}{c}-0.21 \\
(-0.61)\end{array}$ & & $\begin{array}{c}-0.44 \\
(-0.97)\end{array}$ & & $\begin{array}{c}-0.21 \\
(-0.65)\end{array}$ & & $\begin{array}{c}-0.24 \\
(-0.85)\end{array}$ & \\
\hline Majority government & $\begin{array}{c}-0.19 \\
(-0.50)\end{array}$ & & $\begin{array}{c}-0.21 \\
(-0.60)\end{array}$ & & $\begin{array}{c}-0.17 \\
(-0.37)\end{array}$ & & $\begin{array}{c}-0.11 \\
(-0.35)\end{array}$ & & $\begin{array}{c}-0.09 \\
(-0.34)\end{array}$ & \\
\hline$\Delta \mathrm{EXCH}(\mathrm{t}-1)$ & & $\begin{array}{c}0.02 \\
(1.38) \\
\end{array}$ & & $\begin{array}{l}0.005 \\
(0.45)\end{array}$ & & $\begin{array}{c}0.03 \\
(1.92) \\
\end{array}$ & & $\begin{array}{c}-0.0008 \\
(0.06)\end{array}$ & & $\begin{array}{c}0.05 \\
(0.42)\end{array}$ \\
\hline $\begin{array}{l}\text { N. of observations } \\
\chi^{2} \text { test of over. restrictions } \\
\text { p-value }\end{array}$ & & & & & & & & & & \\
\hline
\end{tabular}

Notes: Simultaneous equations approach. Estimation by AGLS technique. Dependent variables: Success $\left(\mathrm{S}^{*}\right)$ and real per capita GDP growth rate (Growth). $\mathrm{S}^{\mathrm{e}}$ variable measuring agents' expectations about $\mathrm{S}^{*} . \Delta \mathrm{G}=$ change in cyclically adjusted primary spending as a share of GDP. $\Delta \mathrm{T}=$ change in cyclically adjusted government revenue as a share of GDP. $\Delta \mathrm{EG}=$ percentage change in public employment. $\Delta \mathrm{CW}=$ change in government wage bill as a share of GDP. $\triangle \mathrm{LABT}=$ change in cyclically adjusted labor taxes' revenue as a share of GDP. Growth G7 = average real per capita GDP growth of the G7 countries. Deficit/GDP = government deficit as a share of GDP. Debt/GDP = public debt as a share of GDP. Left $=1$ if government in office is left oriented, and zero otherwise. Centre $=1$ if government in office is center oriented, and zero otherwise. Majority $=1$ if a single party has the majority in the Parliament, and zero otherwise. $\triangle \mathrm{EXCH}=$ percentage change in the nominal effective exchange rate (a minus sign indicates a nominal devaluation). See also the Data Appendix. Country fixed effects are included. tstatistics in parenthesis. 


\section{Figure 1: Gross General Government Debt}

Average across OECD countries

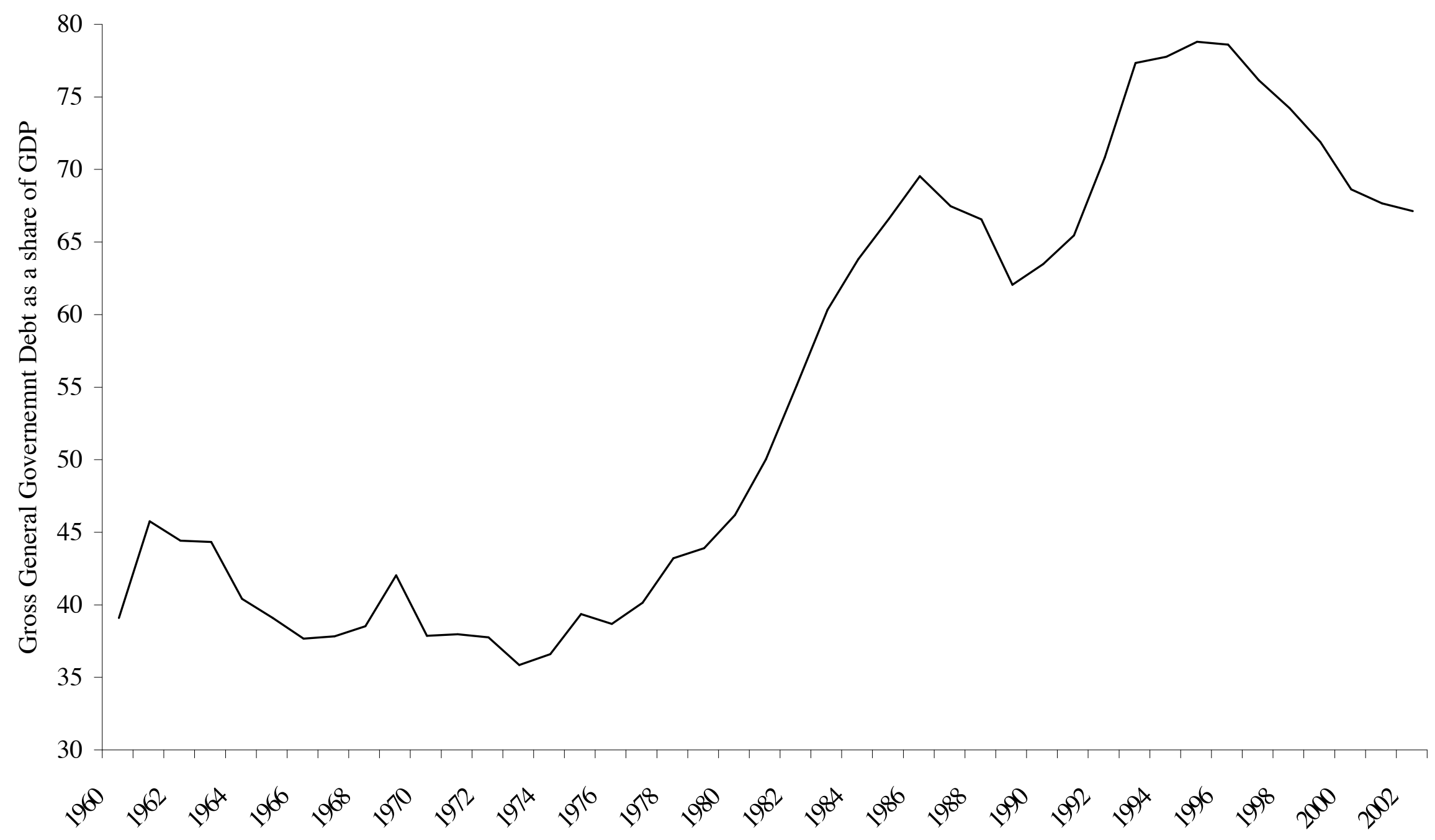

